\title{
1 KASIM 2015 GENEL SEÇIMLERI ÖRNEĞiNDE SIYASI PARTi LIDERLERININ TWITTER KULLANIM PRATIKLERI
}

Neslihan Ölçer ${ }^{1}$

\begin{abstract}
öz
Siyasal iletişim seçmen tercihini etkilemeyi amaçlayan, parti ve liderlerin istekleri doğrultusunda siyasete yön veren ikna edici bir iletişimdir. Siyasal alanda rekabet, siyasal parti ve siyasetçilerin rakiplerinden farklılaşacak iletişim stratejileri uygulamalarını gerektirmektedir. Günümüzde hedef kitlelere ulaşmada geleneksel iletişim araçları yanında daha etkili olabilecek internet ve sosyal medyanın kullanımı dikkat çekmektedir. Bu bağlamda bu çalışmada, 1 Kasım 2015 Genel Seçimlerinde mecliste temsil hakkı bulan dört siyasi parti liderinin seçim kampanyaları kapsamında Twitter kullanım pratiklerinin irdelenmesi amaçlanmaktadır. Adalet ve Kalkınma Partisi (Ak Parti), Cumhuriyet Halk Partisi (CHP), Milliyetçi Hareket Partisi (MHP) ve Halkların Demokrasi Partisi (HDP) liderlerinin 8 Haziran - 1 Kasım 2015 tarihleri arasında Twitter kullanım pratikleri niceliksel içerik analizi yöntemi kullanılarak incelenmiştir. Çalışma kapsamında elde edilen bulgular parti liderlerinin farklı kullanım pratiklerine işaret etmektedir. Özellikle, Twitter'ın etkileşimsellik özelliğini arttıran mention, retweet, hashgtag gibi uygulamaları verimli kullanma bağlamında, liderler arasında önemli farklılıklar tespit edilmiştir. İçerik üretimine olanak sağlayan, katılımcılığı arttıran Twitter gibi sosyal ağların seçmen kitle ile iletişimin geliştirilebilmesi ve beklentilerin yansıtılabilmesi açısından verimli kullanımının seçim kampanyalarının başarısı üzerinde etkin bir rol oynayabileceği söylenebilir. Bununla birlikte, siyasal kampanyaların seçmen kitle üzerindeki etki gücünü arttırabilmek amacıyla yeni medyanın geleneksel iletişim araçlarıyla birlikte kullanılması gerektiği göz ardı edilmemelidir. Bu çalışma siyasi liderlerin 1 Kasım 2015 Genel seçimlerinde Twitter kullanım biçimleri ve yoğunluklarını ortaya koyması açısından önem taşımaktadir.
\end{abstract}

Anahtar Kelimeler: Siyasal iletişim, siyasi parti liderleri, 1 Kasım 2015 Genel Seçimleri, Twitter

\section{PRACTICALS OF TWITTER USE BY POLITICAL PARTY LEADERS IN THE 1st NOVEMBER, 2015 GENERAL ELECTION}

\begin{abstract}
Political communication is a persuasive communication that gives direction of parties and leaders requests and aims to effect voter's preference. Political competition requires communication strategy applications which will differentiate political parties and politicians from competitors. Nowadays, in addition to traditional communication tools, the use of internet and social media, which can be more effective to reach target groups, attracts attention. This study examines the practical use of Twitter in the scope of the election campaign of the leaders of four political parties which are entitled to representation in parliament, in the 1st November, 2015. Quantitative content analysis method is examined on the practices of Twitter usage of Leaders of The Justice and Development Party (AK Parti), The Republican People's Party (CHP), The Nationalist Movement 1 Kocaeli Üniversitesi Sosyal Bilimler Enstitüsü Halkla İlişkiler ve Tanıtım ABD Doktora öğrencisi
nolcer@hotmail.com.tr
\end{abstract}


Party (MHP) and People's Democratic Party (HDP) (between the 8th June to November the 1st, 2015. In the study, the main results are pointing to various application practices of party leaders. Especially, the applications such as "mention", "retweet", "hashgtag" which enhance the transactional property of the Twitter differs in terms of party leaders. In order to improve the communication with the voter audience and in terms of reflection of expectations, the efficient use of social networks such as Twitter which inceases participation, and which allows production of user content. However, the new media which can increase the potency of political campaign must be used in conjuction with traditional communication tools. This study is important for demonstrating the usage patterns and densities of Twitter used by political party leaders in November the 1st, 2015 General Election.

Key Words: Political communication, political party leaders, November the 1st, 2015 Genereal Elections, Twitter

\section{Giriş}

Sosyal bir varlık olan insanlığın bir arada yaşayabilmesinin temel koşulu olarak görülen iletişim, insanlık tarihi boyunca teknolojinin gelişimine bağlı olarak şekillenmiştir. İlkel insanın dumanla haberleşmesinden günümüzde akıllı telefonla haberleşilen bir boyuta gelinmiştir. Bilgi, duygu ve düşüncelerin paylaşılmasında rol oynayan iletişim, ister kişilerarası isterse kitle iletişimi düzeyinde olsun, bir paylaşma eylemi olmanın yanında ikna amacı da taşımaktadır. İkna edici iletişimin etkili kullanıldığı alanlardan biri de siyasal alandır.

Siyasal iletişim sürecinin görünen yüzü olarak ifade edebileceğimiz siyasal seçim kampanyaları seçme hakkını elde etmiş bireylerin seçim tercihlerini etkilemeyi amaçlamaktadır. Siyasal bir kampanyanın başarısı bütün iletişim çalışmalarının birbirini tamamladığı, gündemi takip eden ve gerektiğinde gündemi yaratabilen, hedef kitleleri ile buluşabileceği ortamlar oluşturan bir strateji izlemesi ile olanaklıdır. Bu bağlamda siyasi partiler ve liderleri günümüzde geleneksel iletişim araçları yanında yeni iletişim araç ve ortamlarını etkili bir şekilde kullanmak zorundadir.

Siyasi parti liderlerinin anaakım medyada iddia edilen kutuplaşmaya alternatif yeni mecra arayışları dolayısıyla, siyasi parti ve liderlerin sosyal medyaya yöneldikleri ve sosyal medya kullanım düzeylerinin giderek arttı̆̆ı görülmektedir.

İnternet siyasal yaşam ilişkisi çok boyutlu ve karmaşı bir yapı göstermektedir. Bu karmaşıklık sadece siyasal yaşama özgü olmayıp, internetin gelişimini sürdüren teknolojiyi ifade etmesi ve gelecekteki kullanımında hukuksal, 
idari ve ekonomik faktörlere ilişkin belirsizliklerle tanımlanmasından kaynaklanmaktadır. Bununla birlikte internetin siyasal yaşam öğeleri arasında etkili bir konuma yerleşip siyasal iletişimin entegre bir parçası olma yolunda ilerlediği söylenebilir (Kalkan vd., 2012).

İnternet alanında yaşanan gelişimler ve Web 2.0 devrimi günlük yaşamda meydana gelen değişimlerle birlikte siyasal alana da yansımakta ve siyasal iletişimin yöntemini değiştirmektedir. Sosyal medya vatandaşlar için yeni bir siyasallaşma aracı haline gelmekte ve kendilerini ifade edecek bir araca dönüşmektedir. Yeni siyasal iletişim şekli sosyal medya merkezlidir ve siyasal iletişime yeni bir boyut kazandırmaktadır (Bostancı, 2014: 88).

$\mathrm{Bu}$ çalışma, siyasal iletişim ve sosyal medya ilişkisini incelerken, 1 Kasım 2015 Genel Seçimlerinde mecliste temsil hakkı bulan dört siyasi parti liderinin seçim kampanyaları kapsamında Twitter kullanım pratiklerini ortaya koymayı amaçlamaktadır. Araştırma, siyasi liderlerin siyasal kampanya sürecinde sosyal medyayı kullanım yoğunluklarını ölçmek açısından önem taşımaktadır. Araştırmada liderlerin sosyal medya kullanımı içerik analizi yöntemi kullanılarak analiz edilmiştir.

\section{Siyasal İletişim}

Wolton'a göre siyasal iletişim, "seçmen ikna stratejisi” ve "seçim iletişimi" kavramlarından çok daha geniş bir anlama sahiptir. Siyasal iletişimin önceleri hükümet ile seçmen kitlesi arasındaki iletişimi olarak belirlenen anlamı daha sonra iktidar ve muhalefet siyasetçileri arasındaki iletişime yönelik tanımlanmıştır. Sonraları ise kamuoyunun ilgi alanları ve siyasetçilerin davranışları arasındaki ayrılıkları inceleme şeklinde daha geniş bir çerçevede ele alınmıştır. Günümüzde ise iletişimin siyasal alandaki rolü medya, kamuoyu yoklamaları, siyasal pazarlama ve reklamcılığı kapsayacak şekilde ifade edilmektedir (Wolton 1990'dan Akt., Yıldırım, 2012: 201).

Siyasal iletişim geniş kapsamlı bir kavram olmakla birlikte en yalın haliyle Aziz’e göre (2014: 3) siyasal aktörlerin belli ideolojik amaçlarını, politikalarını belli gruplara, kitlelere, ülkelere veya bloklara kabul ettirmek ve gerektiğinde eyleme 
dönüştürmek, uygulamaya koymak üzere çeşitli iletişim tür ve tekniklerini kullanmalarıdır. Siyasal iletişim kavramı seçim dönemlerinde iktidara gelme amaçlı iletişim çalışmalarından çok siyasete ilişkin tüm iletişim alanlarını kapsamaktadır. Siyasi partilerin seçmeni ikna etmeye yönelik taktiklerinin ötesinde oy verme, demokrasi, iletişim araç ve tekniklerinin gelişimi sonrasında ihtiyaç duyulan daha spesifik bir alandır (Aktaş, 2004: 49).

Siyasal iletişim siyasal aktivitenin geçmişi kadar eski değildir. Siyasi liderler her dönemde kendileri topluma anlatmak ve rakiplerine karşı halkın desteğini elde etmek için çabalamıştır. Günümüzde de var olan bu anlayış Antik Yunan ve Roma’ya kadar götürülebilir. Tarihsel süreçte bu iletişim sadece liderlerden halkla doğru gerçekleşmiş ve medya da bu tek yönlü iletişimde geniş kitlelere ulaşmak için kullanılmıştır. Siyasi sistemlerin demokratikleşerek siyasal aktivitenin kamusal alana yayılması siyasal iletişimin işleyişini değiştirmiştir. Bilgi erişiminin kolaylığı ve eğitim düzeyinin artması vatandaşın siyasal iletişimde aktif olarak yer almasını sağlamıştır (Lilleker, 2013: 15)

Siyasal iletişim demokrasiyle yakından ilişkili bir kavram olarak kitlelere genel oy hakkının verilmesi ile başlamış ve kitle iletişim alanında meydana gelen değişim ve gelişmelerle bugünkü anlamına ulaşmıştır. Siyasal iletişimin anlama ve anlatma işlevi önemli bir fonksiyon üstlenmektedir. Farklı aktörler tarafından dile getirilen ve medya tarafından aktarılan siyasal söylemlerin üretim ve değişimine yönelik her türlü çaba siyasal iletişimi oluşturmaktadır (Özsoy, 2009: 22).

Kendi ideolojilerini egemen kılmak ve toplumsal anlamda meşruiyet kazanmak açısından siyasi aktörler için iletişim önem taşımaktadır. Siyasal iletişim siyasete ilişkin tüm alanları kapsamakla birlikte özellikle seçim dönemlerinde siyasilerin düşünce ve eylemlerinin bir yansıması olarak ortaya çıkmaktadır. İstenen yönde düşünce ve davranış değişikliği oluşturmak ve bunun sürekliliğini sağlama gereksinimi siyasal iletişimi zorunlu kılmaktadır (Yalın, 2006: 170).

İletişimin temelinde yer alan ikna edicilik siyasal iletişimde siyasal aktörlerin iletişim araç ve teknikleri ile seçmeni etkilemesidir. Siyasal iletişim süreci ile normal iletişim arasındaki en önemli fark mesaj gönderen konumundaki aktörün siyasi bir 
kimliğe sahip olmasıdır. Siyasal iletişim mesajları iknaya dayalı bir kamuoyu yaratma amacına odaklandığından etki gücü yüksektir. Siyasal iletişimin başarısında siyasi aktörler, etkili mesaj ve hedef kitle ön plana çıkmaktadır (Kılıçarslan, 2008: 36).

Siyasal iletişimde de iletişim olgu ve sürecinde yer alan verici, alıcı, kanal, mesaj ve geribildirim öğeleri bulunmakla birlikte birtakım farklılıklardan da söz edilebilmektedir (Aziz, 2014: 5):

Verici/kaynakta farklılık: Siyasal iletişimde mesajlar çoğunlukla ya da doğrudan siyasi kimliği olan bir yapıdan, organizasyondan, kurumdan veya topluluk adına hareket eden bir kişi, grup tarafindan verilir.

Alıcıda farklılık: Siyasal iletişimin ulaşmak istediği hedef kitle genellikle seçme hakkını almış genç ve yetişkinlerdir.

Mesajda farklılık: Siyasal iletişimde verilen mesajlar siyasal amaçlıdır ve hedef kitlenin simge ve anlamları ile örtüşmelidir.

Kanal/Yöntem farklılı̆̆g: Hedef kitle özellikleri göz önünde bulundurularak kullanılacak yöntem, araç ve teknikler kullanılmalıdır.

Geribildirimde farklılık: Siyasal iletişimde kullanılacak yöntem ve teknikler geribildirime olanak sağlayacak türde olmalıdır.

Siyasal parti ve adayların seçmenlere yönelik olağan ve seçim dönemlerinde gerçekleştireceği iletişim, kuruma ve adaya yönelik imajın yapılandırılmasında etkilidir. Bu durum siyasi aktörlerin hedef kitle ile iletişime geçeceği tüm iletişim kanallarının etkili kullanımını gerektirmektedir. Özellikle iletişim teknolojilerinin gelişmesi ve buna bağlı araçların kullanımının artması siyasileri hedef kitle ile iletişim kuracakları her alanda varolma çabasına itmektedir.

Siyasal iletişim tek yönü bir iletişim değildir. Seçmenlerin siyasal etkinlik ve bilgi düzeylerinin bilinmesi, topluma iletilen mesajların nasıl algılandığının tespiti siyasal iletişim başarısında önemli bir rol oynar. Alınan geri bildirimler sonucunda siyasal iletişimin stratejisi belirlenir (Özkan, 2007: 148). Siyasal iletişim, tarihsel 
süreçte tek yönü bilgi akışına dayanan anlayışı değiştirerek özellikle geri bildirim alacağı iletişim araçlarının kullanımını yaygınlaştırmaktadır.

\section{Internet Ve Siyasal i̇letişim}

Amerika Birleşik Devletleri (ABD) Savunma Bakanlığı tarafından askeri amaçlı araştırma birimlerini birbirine bağlamak amacıyla geliştirilen ARPANET, 1990 yılında internet adıyla günümüzde milyonlarca insanı birbirine bağlayan gelişkin sivil ağa dönüşmüştür. İnternetin tüm dünyada hızlı bir şekilde yaygınlaşmasıyla birlikte ekonomi, sağlık, kültür sanat, eğlence vb. pek çok alanda spesifik amaçlı kullanımının artması siyasal amaçlı kullanımını da beraberinde getirmiştir (Öksüz ve Yıldız, 2004: 994).

Kendisi de bir kitle iletişim aracı olan internet, mevcut kitle iletişim araçlarında yapısal ve biçimsel değişimlere neden olmaktadır. Siyasal partiler haber ve bilgi akışını aracısız bir şekilde bu ortamda kontrol ederken aynı zamanda seçmenleri ile etkileşim kurabilmektedir. Siyasal parti üyeliklerinin sayısının artması yanında, finansal desteğin elde edilmesinde de internet rol oynamaktadır. Geleneksel kitle iletişim araçlarının desteğini alamayan aşırı uçtaki siyasal partiler hedef kitlelerine ulaşmada düşük maliyetli ve daha özgür olarak kabul edilebilecek internete yönelmektedir. Ayrıca internete yönelmenin diğer bir nedeni de mevcut koşulların gerisinde kalmayan kendini yenileyen modern bir izlenim yaratabilmektir (Öksüz ve Yıldız, 2004: 994).

Demokrasinin temelinde bireyler arasındaki etkileşimin yer aldığı göz önünde bulundurulursa bireyler arasındaki karşılıklı etkileşimin varlığı katılımın yaygınlaşması ve sistematikleşmesini sağlamaktadır. Demokrasinin gelişebilmesi bireylerin sağlıklı iletişim kurabilmesi ve sisteme katılımı ile olanaklıdır. Siyasete ve siyasal kararların alınması sürecine katılım geleneksel iletişim araçları yanında yeni iletişim teknolojilerinin sağladı̆̆ı ortamlar ile gerçekleşmektedir. İnternet başta olmak üzere yeni iletişim teknolojileri halkın siyasete katılım düzeyini arttırarak demokrasinin daha karmaşık bir yapıya bürünmesini sağlamıştır. Bununla birlikte yeni ortam ve araçlar seçim dönemlerinde oy verme davranışı üzerinde etkide bulunurken, siyasal tartışmaların yapılabildiği bir alan da yaratmaktadır. Yeni 
iletişim teknolojileri demokrasinin gelişimine katkı sağladığı gibi farklı görüş ve düşüncelerin ifade edilebildiği bir araç işlevini de görmektedir (Karaçor, 2009: 130).

Siyasi aktörlerin internet ortamını kullanım hedefleri temel olarak iki amaca yönelmektedir. Bunlardan ilki kendini tanıtmak ikincisi ise rakip siyasilerden ve eylemlerinden haber almaktır. Siyasi aktörler içinde siyasi partilerin interneti kullanım amaçları ise internetin sürekli bir siyasal iletişim aracı olarak kullanılmasıdır. Diğer bir neden de siyasal kampanyalar döneminde seçmen oylarını etkilemek için internetin yoğun kullanımıdır (Aziz, 2014: 78).

İnternet ve yeni iletişim teknolojilerinin sağladığı sosyal paylaşım imkanları seçim kampanyalarındaki ideolojik düşüncenin hızlı bir şekilde yayılmasını ve bu ortamın kullanıcısı olan pek çok insanın etkilenmesini sağlamaktadır. Seçim sonuçları üzerinde önemli etkisi olan kararsız seçmenin yeni iletişim teknolojilerinin sağladığı olanaklarla parti lehinde oy kullanması için hızlı, kolay ve etkili bir ortam oluşturmaktadır (Akıncı Vural ve Bat, 2009: 2753).

Yeni iletişim teknolojileriyle birlikte, siyasal iletişim çalışmalarında ilgi, İnternet üzerinde gerçekleşen yeni bir kamusal alan üzerine yönelmiştir (Sütçü, 2007: 72). Siyasal iletişim çalışmalarının seçmen üzerinde istenen ve beklenen yönde değişim yaratması ve bu değişimin siyasi tercihlere yansıması hedeflenmektedir. Günümüzde kullanım oranlarının artışına paralel olarak geleneksel iletişim araçlarının yanında yeni iletişim teknolojilerinin sağladığı ortamlar da insanlar üzerinde önemli etkiler bırakmaktadır. Bu amaçla araştırmalar internet ve sosyal medyanın kullanıcılar üzerindeki genel etkileri yanında siyasal iletişim açısından da etkilerini ölçmeye yönelmiştir. Yeni kamusal alan olarak ifade edilen internetin partilerin siyasal iletişim, demokratik katılım vb. unsurlar üzerinden etkisi çeşitli araştırmacılar tarafından ele alınmaktadır.

\section{Siyasal Iletişim Açısından Sosyal Medya}

1970’lerde başlayıp 1990'larda yaygınlaşmaya başlayan internet kullanımı, web siteleri, portalların gelişmesi ve sosyal medyanın işlerlik kazanmasıyla geniş bir kitlenin dikkatini çekmeye başlamıştır. Yeni iletişim ortamlarının gelişmesi, bilgi iletişim teknolojilerine ilginin artması sosyal medyanın gücünü arttırarak 
sosyalleşme kavramına yeni bir boyut getirmiştir. Sosyal medyanın güncellenebilmesi, çoklu kullanıma açık olması, sanal paylaşıma olanak tanıması, insanların düşüncelerini yazıp tartışabilmesi ve yeni fikirler geliştirebilmesi bu ortamı en ideal mecralardan biri haline getirmektedir. Ayrıca fotoğraf ve video paylaşımı gibi özellikleri dikkatleri bu alana çekerek sanal dünyaya ilişkin bir kavramsal çerçeve çizmeye neden olmaktadır (Akınc1 ve Bat, 2010: 3349). Televizyon ve yazılı basın gibi geleneksel iletişim araçlarının tek yönlülüğü manipülatif olduğu düşündürmekte iken internetin getirdiği Web uygulamaları iletişim kuran taraflar arasında eşzamanlı ve iki yönlü enformasyon akışı sağlamaktadır (Sayımer, 2012: 29).

Sosyal ağların en çok bilinenlerinden Facebook bir milyar dört yüz kırk milyon, Twitter ise 289 milyon aktif kullanıcıya sahiptir (http://www.statisticbrain.com/). Sayıları giderek artan kullanıcı sayıları ve sosyal medyada geçiren süreler bireye zaman ve mekan sınırı getirmeden (mobil cihazlar) ulaşma imkanı sağlaması nedeniyle reklamcılar, pazarlamacılar, halkla ilişkiler uzmanları ya da seçmenle iletişim kurma çabası içinde olan siyasiler tarafindan da ilgi çekici bir mecra olarak kabul edilmektedir.

Sürekli gelişen teknoloji ile hedef kitle ile iletişim kurma amaçlı yöntemler şekillenmekte ve bu durum siyasal iletişim çalışmalarına da yansımaktadır. $\mathrm{Bu}$ yansıma ile birlikte yeni araç ve yöntemlere ilgi gösterilmekte ve giderek kullanıcı sayısı artmaktadır. Siyasi partiler ve parti liderleri de Facebook, Twitter, Youtube gibi araçları kullanmaya önem vermekte, parti ve bireysel hesaplar ile bu ortama katılmaktadırlar. Afiş, video, reklam gibi geleneksel araçlar bu mecrada da paylaşılabilmekte, siyasal iletişim çalışmaları bütünleşik iletişim çalışmalarına olanak veren sosyal medya üzerinden yürütülebilmekte ve etkileşimli bir ortam yaratılabilmektedir. Sosyal medya hedef kitlelere yakınlaşma, bilgilendirme, hız ve interaktiflik sağlamaktadır (Öztürk, 2014: 400).

Sosyal medya ile birlikte tek yönlü bilgi paylaşımı çift yönlü etkileşimsel bir şekilde gerçekleşmeye başlamış, kişilerin internet üzerinden özgürce, zaman ve mekan sınırı olmadan diyaloğa geçmesine ve paylaşımların artmasına yol açmıştır. $\mathrm{Bu}$ sayede bireylerin paylaşımları, sanal dünyada birer değere kavuşarak yeni bir 
özgürlük alanı oluşturarak, sosyal medya bireyin egemenlik ve iletişim şekli olarak ortaya çıkmıştır (Tamçelik, 2014: 28). Sosyal medyanın hızlı, az maliyetli ve etkileşimsellik özelliği gösteren yapısı nedeniyle bir ikna edici iletişim olarak siyasal iletişimin dikkatini çektiğini söylemek gerekmektedir. Özellikle bireylere fikirlerini ifade edecekleri ve siyasi aktörlerle iletişime geçecekleri bir ortam yaratması farklı görüşlerin dillendirilebileceği imkanlar sunmaktadır. Sosyal ağların kullanımının gençler arasındaki yaygınlığ 1 siyasi liderler ve partilerin bu ortamı etkili şekilde kullanmalarını gerektirmektedir. Bununla birlikte Türkiye'de sosyal medyanın siyasi katılıma etkileri konulu bir araştırma sosyo-ekonomik düzeyin yüksekliği ve ilerleyen yaşın siyasete ilgi ve sosyal ağlarda siyasi katılımı arttırdığına işaret etmektedir. Yeni medya okuryazarı gençlerin sosyal ağlarda siyasi içerik ve aktörleri takibi diğer yaş gruplarına göre daha az iken yaş aralığının yükselmesi siyasete ilgi düzeyi, kendilerini siyasi bir kimlikle tanımlama ve sosyal medyada siyasi paylaşımda bulunma oranını artmaktadır (Şener vd., 2015: 94-95).

Siyasetin sosyal medya ile ilişkisinde üç önemli olaydan söz edilebilmektedir. Birincisi Obama'nın sosyal medya odaklı gösterisi, ikincisi Ortadoğu'da etkili olan Arap Baharı ve üçüncüsü de Gezi Parkı olaylarıdır. 2008 ABD Başkanlık seçimlerine kadar geleneksel medya seçim kampanyalarında başat rol oynamıştır. 2008 seçimleri ise sosyal medyanın aktif kullanıldığı ve sosyal medyanın siyasal iletişimdeki etkisiyle Obama'ya zafer kazandıran bir seçim olmuştur. Önemli bir halk hareketi olarak karşımıza çıkan Arap Baharı sürecinde de geleneksel medyanın sansürlenmesi karşısında sosyal medya üzerinden organize olunarak uluslararası medyanın dikkati çekilmiştir. Ülkemizde gerçekleşen Gezi Parkı olayları da sosyal medyada örgütlenme ve harekete geçebilme bağlamında dikkat çekmektedir (Bostanc1, 2014: 86).

Siyasal aktörler ve seçmenler internet, elektronik posta ya da chat yerine Facebook, Twitter gibi sosyal medya ortamlarını kullanmaya başlamış, yorum, beğeni, retweet, tweet gibi kavramlar ön plana çıkmıştır. Siyasiler en hızlı ve etkili şekilde seçmene ulaşacakları ortam olarak sosyal medyayı yoğun olarak kullanmaya başlamışlardır (Bostancı, 2014: 88). Özellikle genç seçmenin zamanının büyük 
bölümünü geçirdiği bu ortam onlara ulaşabilmek ve parti görüşlerinden haberdar edebilmek, partiye yeni üyeler katabilmek adına tercih edilmektedir.

İnternet kullanımının artışına paralel olarak sosyal medya siyasal kampanyaların yürütülmesinde en aktif araçlardan biri haline gelmektedir. Özellikle Barack Obama’nın 2008 başkanlık seçimlerinde Facebook ve Twitter gibi sosyal medya hesaplarını seçim kampanyasında aktif kullanımı ve seçim sonuçlarına olan etkisi siyasal iletişimde sosyal medyanın önemini ortaya koymaktadır.

Seçim kampanyalarında kullanılan iletişim stratejilerinin tartışıldığ 1 "Hedef: Hedef Kitle" konferansında söz alan Barack Obama'nın 2012 Başkanlık seçimlerinde ulusal saha direktörü olarak görev yapan Jeremy Bird başarılı bir kampanyanın, iyi bir aday, güçlü ve somut mesajlar, dijital ve saha çalışmalarının entegrasyonu ile mümkün olabileceğini belirtmiştir. 2012 ABD Başkanlık seçimlerinde Obama'nın digital kampanya direktörlüğü görevini üstlenen Teddy Goff ise insanların eskisi gibi CNN izlemek yerine Facebook ve Twitter'da daha çok vakit geçirdiğini ifade ederken seçim kampanyalarında pozitif bir dil kullandıklarının da altını çizmektedir. Goff, ayrıca siyasal kampanyada internetin aktif kullanımına dikkat çekerek, internet üzerinden 690 milyon doların üzerinde bağış toplanıp, 1 milyondan fazla seçmen kaydedildiği Facebook’ta 45, Twitter'da 33 milyon takipçi toplandığını bildirmektedir (www.internethaber.com).

\section{Siyasal İletişim Açısından Twitter Kullanımı}

2006 y1lında Jack Dorsey tarafından geliştirilmiş olan Twitter, bir sosyal ağ ve mikroblog sitesidir. 140 karakterlik metin yazma imkanı veren Twitter kullanıcılar tarafından atılan tweetlerin herkes tarafından görülebileceği bir ortamdır (tr.wikipedia.org).

Web 2.0 teknolojisi kullanıcıları hem içeriği tüketen hem de üreten anlamında tüketen üretici olarak tanımlamaktadır. Kullanıcılar blog, wiki, sosyal ağlar gibi Web 2.0 teknolojilerini kullanarak uzmanlık gerektirmeden içerik üretip, güncelleyip, paylaşabilmektedir. Kullanıcıların duruma yönelik anlık iletiler paylaştığı, resim, video ve farklı sayfaların linklerine yer verebildikleri Twitter popüler bir sosyal ağ sitesi olarak gün geçtikçe kullanıcı sayısını arttırmaktadır. İfade 
ve durumların metin ile aktarılmasının 140 karakter ile sınırlı olması Twitter'ın mikroblog özelliğini, takipçiler aracılı̆̆ı ile ağ içinde yayılması da, sosyal ăg özelliğini göstermektedir (Odabaşı vd., 2012: 94).

Endüstri Devrimi sonrası toplumun zaman çizelgesi (çalışma, dinlenme vb) esas alınarak oluşturulan geleneksel medyadaki akış sosyal paylaşım ağlarında kullanıcıların günlük yaşamlarında kişisel zaman çizelgelerine göre oluşturulabilmektedir. Twitter kullanıcılara kendi akışlarını oluşturabilecekleri olanak sağlarken, geleneksel medyadaki tek yönlülükten farklı etkileşimli ve kullanıcıların aktif olarak seçip oluşturdukları kişiye özgü bir akışı olanaklı k1lmaktadır (Altunay, 2010: 38).

Twitter toplumu ilgilendiren konulara ilişkin 140 karakterle çok sayıda ağ üzerinden aynı konu hakkında fikirleri paylaşma imkânı yaratmaktadır. Bu ortam gündem oluşturup benzer düşünen insanları aynı konu etrafında toplayabilmektedir. Yeni medyanın etkileşimsellik özelliği ile kamusal bir alana dönüşen sosyal medyanın gücü siyasetçilerin de kendini meşrulaştırma ve onay aracı olarak kullanımına yol açmaktadır (Çetin, 2015: 94).

Diğer iletişim araçlarıyla, rahatlıkla rekabet edebilecek olan Twitter'in kullanım nedenlerini Jose Van Dick şöyle sıralamaktadır (Van Dijck 2011'den Akt., Bayraktutan vd. 2012: 16):

1. Sohbet ve diyalog

2. Dayanışma ve değişimi mümkün kılması

3. Öz-ifade ve öz-iletişimi mümkün kılması

4. Statü güncelleme ve kontrol etme

5. Bilgi ve haber paylaşımı

6. Konum, ilgi alanları ve bağlantılarla ilişkili olarak pazarlama ve reklam.

Dale'e göre, kişiler, kurumlar, siyasal partiler, sivil toplum grupları vb. topluluklar Twitter'ı sosyal iletişim aracı olarak kullanmaktadırlar. Özellikle SMS kadar kısa, internet kadar etkili olması ve halkla ilişkiler görevini yerine getirmesi 
nedeniyle Twitter'ın kullanıcısı giderek artmıştır (Dale 2009'dan Akt., Tamçelik, 2014: 31).

Siyasi katılım ve sosyal medya kullanımını belirlemeye yönelik pek çok araştırma yapılmıştır. Örneğin; 410 sosyal medya kullanıcısı ile yapılan bir araştırmada, bir siyasi parti üyesi olmasa da kullanıcıların sosyal medyada siyasi paylaşımda bulundukları, Twitter kullanıcılarının daha çok siyasallaştığı ve sosyal medyadaki siyasi içeriklerin siyasi tercihleri etkilediği sonucuna ulaşılmıştır (Bostanc1, 2014: 86).

\section{Milliyetçi Hareket Partisi'nin Alternatif Mecra Arayışında 2011 Genel} Seçimleri ve Twitter Kullanımı başlıklı çalışmada, partinin Twitter'ı özellikle kampanya etkinliklerinin arttığı dönemlerde daha çok kullandığı belirtilmektedir. Bununla birlikte, ayrı gündem konularının da yer aldığı Twitter, siyasi ideolojilerin sergilendiği bir alan ve parti temsilinin bir uzantısı olmasının ötesinde çok yönlü bir platform olarak görülmektedir (Doğu vd., 2013: 123).

Tumasjan vd.'nin (2010: 184) yaptığı çalışma, Alman Federal seçimlerinde Twitter'ın siyasi müzakere için yaygın olarak kullanılabilen bir araç olduğunu göstermektedir. Çalışma sonuçları, Twitter'ın siyasi görüşler için geçerli bir gösterge ve geleneksel yöntemlerin tamamlayıcısı olabileceğini göstermektedir.

Usage of Social Media for Political Communication başlıklı çalışma sonuçlarına göre, politik partilerin sosyal medya temelli iletişimine Alman seçmenlerin artan ilgisi dikkat çekmektedir. Son y1llarda özellikle sol eğilimli partiler ve Alman politikacılar tarafından sosyal medya kullanımının arttığ gözlemlenmektedir. Dahası, politikacıların çoğunluğunun sosyal medyada yer aldığı, güncel siyasi tartışmalar ile ilgilendikleri, güncel kalmayı, yeni eğilimleri tespit edip, farklı düşüncedeki etkili kullanıcıları tanımayı amaçladıkları tespit edilmektedir (Stieglitz vd., 2012).

Siyasal İletişim Kampanyalarında Sosyal Medyanın Kullanımı: 12 Haziran 2011 Seçimleri Twitter Örneği başlıklı çalışmada ise, Türk politikacılarının sosyal medyaya yabancı kalmadıkları fakat etkili bir şekilde de kullanmadıkları sonucuna ulaşılmıştır. Liderlerin takip ettikleri kişi sayısının azlığı, siyasal kampanya sürecinde 
sosyal medyaya yeterince zaman ayırmamaları, demeç vermenin dişında etkileşimden uzak durmaları dikkat çeken olumsuzluklar olarak ifade edilmektedir (Genel, 2012: 30).

\section{1 Kasım 2015 Genel Seçimlerinde Siyasal Parti Liderlerinin Twitter Kullanım Pratikleri}

Bu çalışmada, 1 Kasım 2015 Genel Seçimleri sonucuna göre mecliste temsil yeteneği bulan siyasi partilerin liderlerinin bir siyasal iletişim aracı olarak Twitter'ı kullanım pratikleri incelenmektedir.

\subsection{Araştırmanının Konusu ve Amacı}

Yeni iletişim teknolojilerinin gelişimine bağlı olarak bireyin yaşamında önemli bir yer edinen internet ve sosyal medyanın siyasi aktörler bağlamında kullanımı da artmaktadır. Bir ikna edici iletişim biçimi olarak siyasal iletişim hedef kitlelerle en etkin, hızlı şekilde etkileşim içinde olmayı hedeflemektedir. Seçim kampanyaları döneminde yoğunlaşmakla birlikte olağan dönem içinde de hedef kitlelere ulaşılabilecek her ortamın değerlendirilmesi kampanya başarısı açısından önem taşımaktadır. Bu bağlamda çift yönlü, eş zamanlı ve görece daha özgür bir ortam kabul edilen sosyal medyanın siyasi partiler ve siyasi parti liderleri açısından kullanımı kaçınılmazdır.

$\mathrm{Bu}$ araştırmanın temel amacı, yeni iletişim teknolojilerinin gelişimine paralel olarak geleneksel medya yanında sosyal medyanın siyasal iletişimde siyasal parti liderleri tarafından kullanım pratiklerini incelemektir. Çalışmada 1 Kasım 2015 seçimleri öncesinde sadece "Twitter” kullanımı ele alınmıştır. Siyasi parti liderlerinin Twitter kullanımındaki benzerlik ve farklılıkları, etkileşimsellik sağlayan unsurları kullanımları tespit edilmeye ve karşılaştırmalı olarak analiz edilmeye çalışılmıştır.

Araştırmanın evrenini 1 Kasım 2015 Genel Seçimlerine katılan 16 siyasi parti liderinin Twitter hesapları oluştururken, örneklemi seçim sonuçlarına göre TBMM'de temsil hakkı bulan Ak Parti, CHP, MHP ve HDP liderlerinin seçim kampanyası döneminde kullandıkları Twitter hesapları oluşturmaktadır. 


\subsection{Araştırmanın Yöntemi}

7 Haziran 2015 Genel Seçimleri sonuçlarına göre tek başına bir siyasal parti hükümet kuracak çoğunluğa ulaşamamıştır. Yapılan koalisyon görüşmeleri sonuç vermemiş ve bir seçim hükümeti ile erken seçime kadar devam edilmesi kararı alınmıştır. 7 Haziran 2015 seçimleri ile seçimlerin tekrarlanmasına karar verilen tarih olan 1 Kasım 2015 arasında siyasilerin seçim kampanyaları devam etmiştir. Sosyal medyanın siyasal kampanyalarda artan etkisi ve etkileşimsellik boyutuyla Twitter siyasal iletişimde liderlerin kullandıkları araçlar arasına girmiştir. Bu bağlamda araştırma, geriye tarama yöntemi ile liderlerin Twitter kullanımlarının karşılaştırmalı bir analizini hedeflemektedir.

Araştırmada, mecliste temsil hakkı bulun dört siyasi partinin liderlerinin 8 Haziran - 1 Kasım 2015 tarihleri arasında Twitter kullanımlarına ilişkin içerik analizi yapılmıştır. İçerik analizi iletişim içeriğinin önceden belirlenen sınıflamalar (kategoriler) çerçevesinde sistematik olarak gerçekleştirilmesini sağlayan araştırma tekniğidir. Metinsel, görsel, işitsel her türlü içerik ve belge içerik çözümlemesi tekniği ile çözümlenebilir (Geray, 2014: 135). Analiz, erken seçim kararı alınması nedeniyle iki seçim dönemi arasında siyasi liderlerin Twitter'daki etkinliğini incelemektedir. Belirlenen aralıkta; tweet sayıs1, Twitter'ın retweet, hashtag, mention, fotoğraf ve video kullanımları ve paylaşımları konu dağılımları boyutları kategorileştirilerek analiz yapılmıştır.

Çalışma kapsamında Sezin Baysal Berkup’un “Bu Siyasal Mesajı Tweetlesek De Mi Paylaşsak Tweetlemesek De Mi Paylaşsak? 2015 Türkiye Genel Seçimlerinde Siyasal Partilerin Twitter Kullanımları Üzerine Karşılaştırmalı Bir Analiz” ile Doğu vd.'in Milliyetçi Hareket Partisi'nin Alternatif Mecra Arayışında 2011 Genel Seçimleri ve Twitter Kullanımı başlıklı makaleleri incelenerek, kategorilerin oluşturulmasında bu çalışmalardan yararlanılmıştır.

\subsection{Bulgular}

7 Haziran 2015 seçimlerinde \%40,66 oy oranı alan Ak Parti lideri Ahmet Davutoğlu, \%25,13 oy oranı ile CHP lideri Kemal Kılıçdaroğlu, \%16,45 oy oranı ile 
MHP lideri Devlet Bahçeli ve \%12, 96 oy oranı ile HDP liderleri Selahattin Demirtaş ve Figen Yüksekdağ'ın Twitter hesaplarına ilişkin bilgiler Tablo 1'de verilmektedir.

Tablo1. Liderlerin Twitter Hesapları

\begin{tabular}{ll}
\hline Parti Lideri & Twitter Adresi \\
\hline Ahmet Davutoğlu & https://twitter.com/Ahmet Davutoglu \\
Kemal Kilıçdaroğlu & $\underline{\text { https://twitter.com/kilicdarogluk }}$ \\
$\begin{array}{l}\text { Devlet Bahçeli } \\
\text { Selahattin }\end{array}$ & $\underline{\text { https://twitter.com/dbdevletbahceli }}$ \\
Demirtaş & $\underline{\text { https://twitter.com/hdpdemirtas }}$ \\
Figen Yüksekdağ & $\underline{\text { https://twitter.com/FigenYuksekdag }}$ \\
\hline
\end{tabular}

Tablo 2'de liderlerin Twitter hesaplarındaki takipçi sayıları gösterilmektedir. En yüksek takipçi sayısı Davutoğlu'na ait iken en düşük takipçi sayısı ise Yüksekdağ'a aittir.

Tablo2. Liderlerin Twitter Hesaplarındaki Takipçi Sayıları

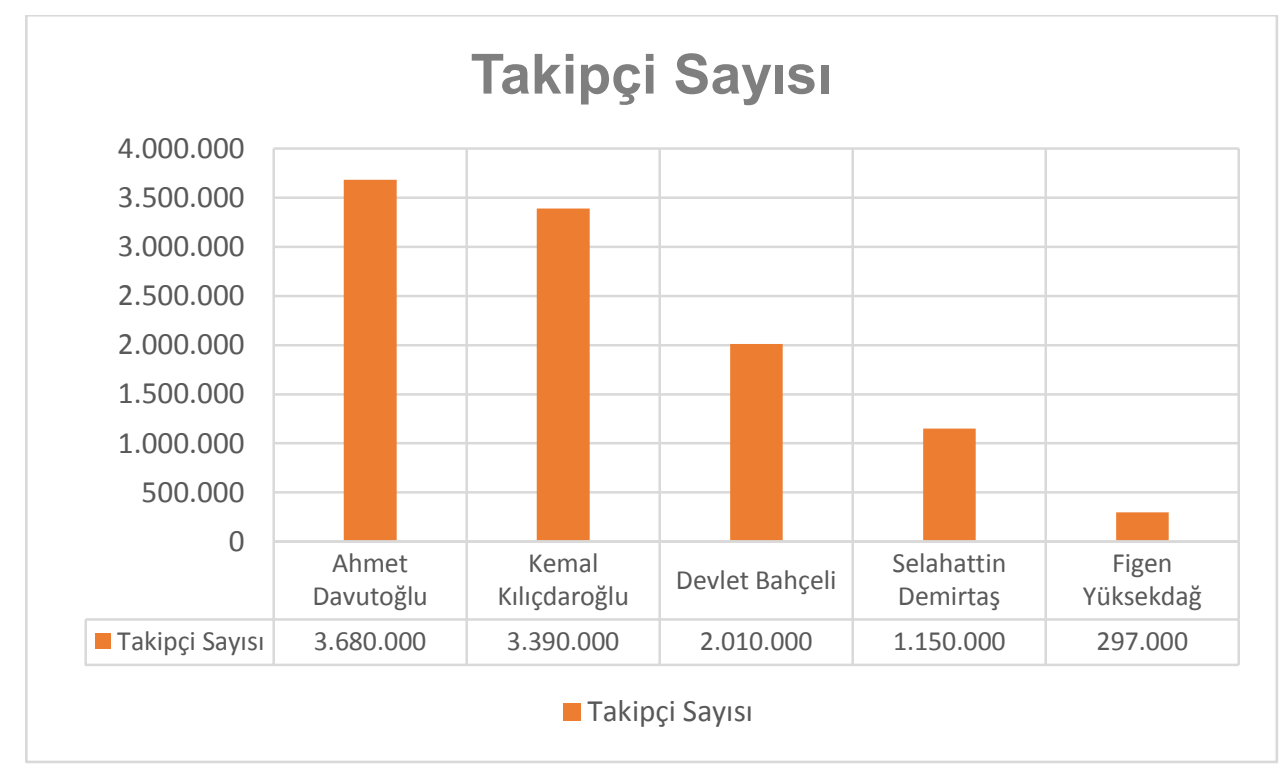

Diğer yandan, takip ettikleri kişi sayısı bağlamında liderler ele alındığında, Davutoğlu'nun en az sayıda kişiyi takip ettiği, ana muhalefet lideri Kılıçdaroğlu'nun ise en çok sayıda kişiyi takip ettiği görülmektedir. Bu konuda en dikkat çekici lider Bahçeli'dir, çünkü Bahçeli hiç bir hesabı takip etmemektedir. Yine dikkat çekici bir diğer durum, Davutoğlu'nun takipçi ve takip edilen hesap sayısı arasındaki farktır. 
Diğer liderler ile karşılaştırıldığında Kılıçdaroğlu'nun takip ettiği hesap sayısı oldukça yüksektir. Bu durum, Twitter ortamının kullanım amacına ilişkin bilgiler de vermektedir. Takip edilen hesap sayısının azlığı liderler açısından seçmene, diğer partilere ve farklı paylaşımlara yönelik ilgisizliğe ve iletişimin tek yönlülüğüne işaret etmektedir. Zira, diğer Twitter hesaplarının takibi hedef kitle ile iletişimin karş111kl11ık özelliğini gözeterek iletişimin yönünü belirleyebilmektedir.

Tablo 3. Liderlerin Hesaplarındaki Takip Edilen Sayısı

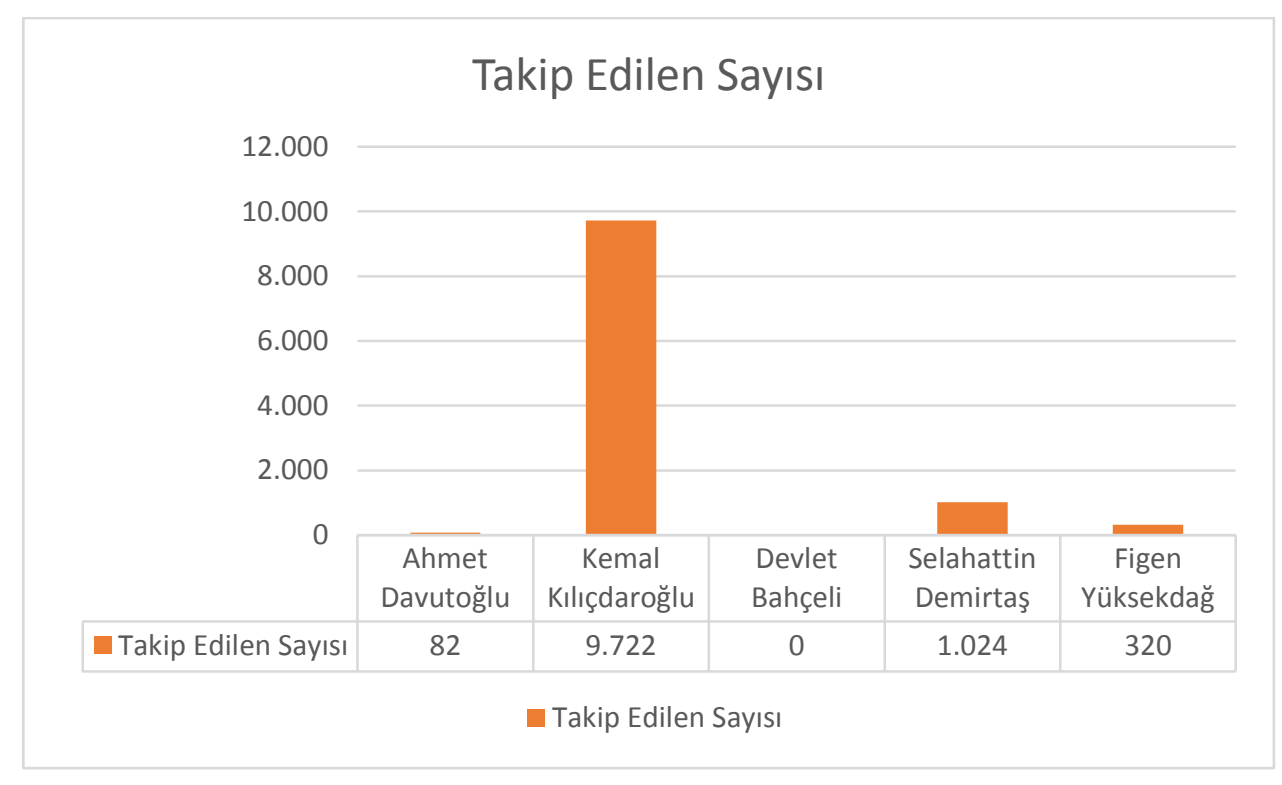

Hesapların aktivitesini ortaya koyabilmek için liderlerin attığı tweet sayısı önemli bir göstergedir. Bahçeli 550 tweet ile en yüksek tweet sayısına sahiptir. Davutoğlu 151 tweet, Kılıçdaroğlu ise 100 tweet gönderirken, Demirtaş ve Yüksekdağ 59 tweet sayısı ile eşit sayıda tweet atmıştır. Bu sonuçlara göre Bahçeli'nin hitabet yerine dolaylı bir iletişim kanalı olan sosyal medyayı yazılı mesaj verme bağlamında yoğun kullandığı dikkati çekmektedir. İncelenen dönem içinde siyasi liderlerin her gün Twitter aktivitesi bulunmamaktadır. 
Tablo 4. Liderlerin Tweet Sayıları

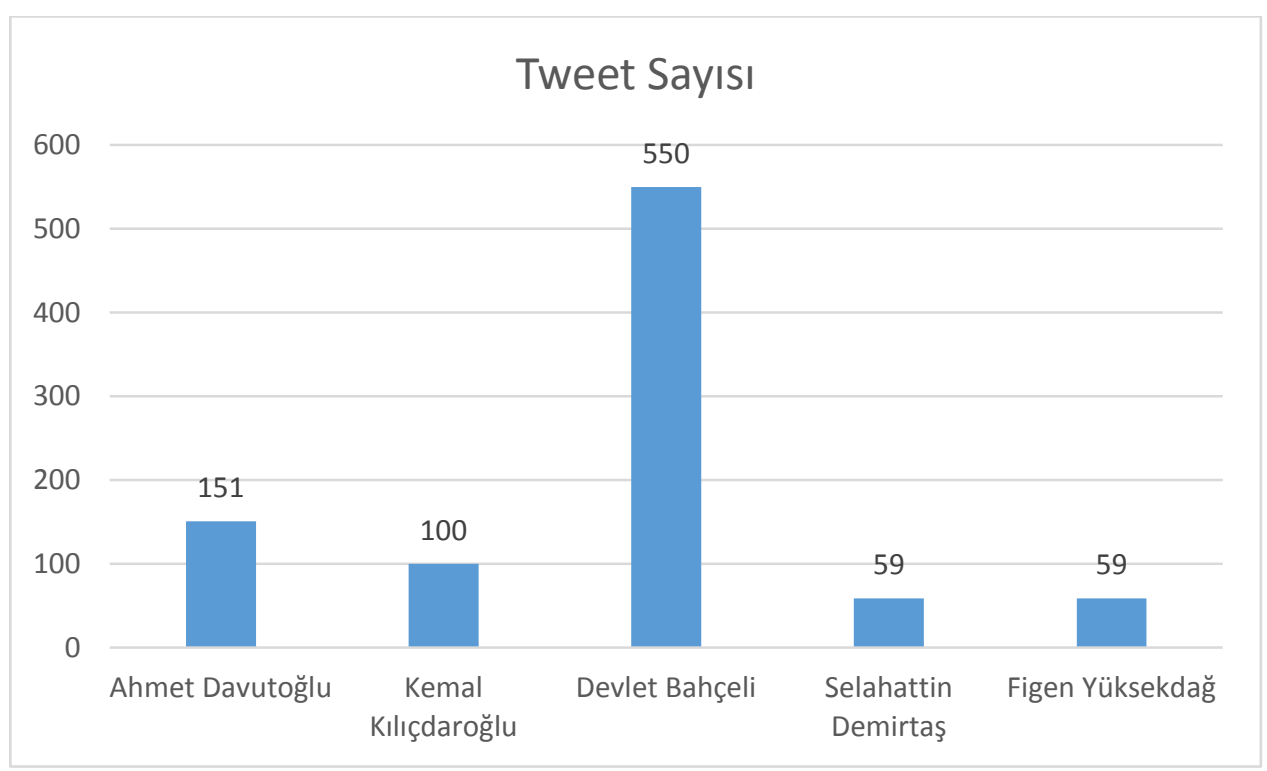

İçeriği başkası tarafından oluşturulmuş bir Twitter mesajını kullanıcının kendi hesabında paylaşması retweet olarak isimlendirilmektedir. Başkası tarafından oluşturulmuş içerik paylaşılarak daha çok kişiye ulaşılmaktadır. Bahçeli bu yönde hiçbir paylaşımda bulunmazken, Davutoğlu, Kılıçdaroğlu ve Demirtaş'ın hesaplarında özgün tweetlere oranla az sayıda olmakla birlikte retweetler bulunmaktadır. Yüksekdağ'ın hesabında ise ağırlıklı olarak retweet kullanılmıştır. Bahçeli’nin Twitter kullanımda gündemdeki pek çok konuya ilişkin düşüncelerini aktarma amacı ön plana çıkmaktadır. Bu nedenle tweetler, çok sayıda, karşılıklı konuşmayı andıran ve birbirini takip eder niteliktedir. Twitter başka paylaşımlar yerine kendi düşüncelerini ifade edeceği bir araç olarak görülmektedir. Yüksekdağ'ın retweet kullanımının yüksekliği ise kendi görüşlerini aktarmaktan çok toplumsal alandaki farklı konulara dikkat çekme beklentisi olarak yorumlanabilir. 
Tablo 5. Liderlerin Retweet Sayıları

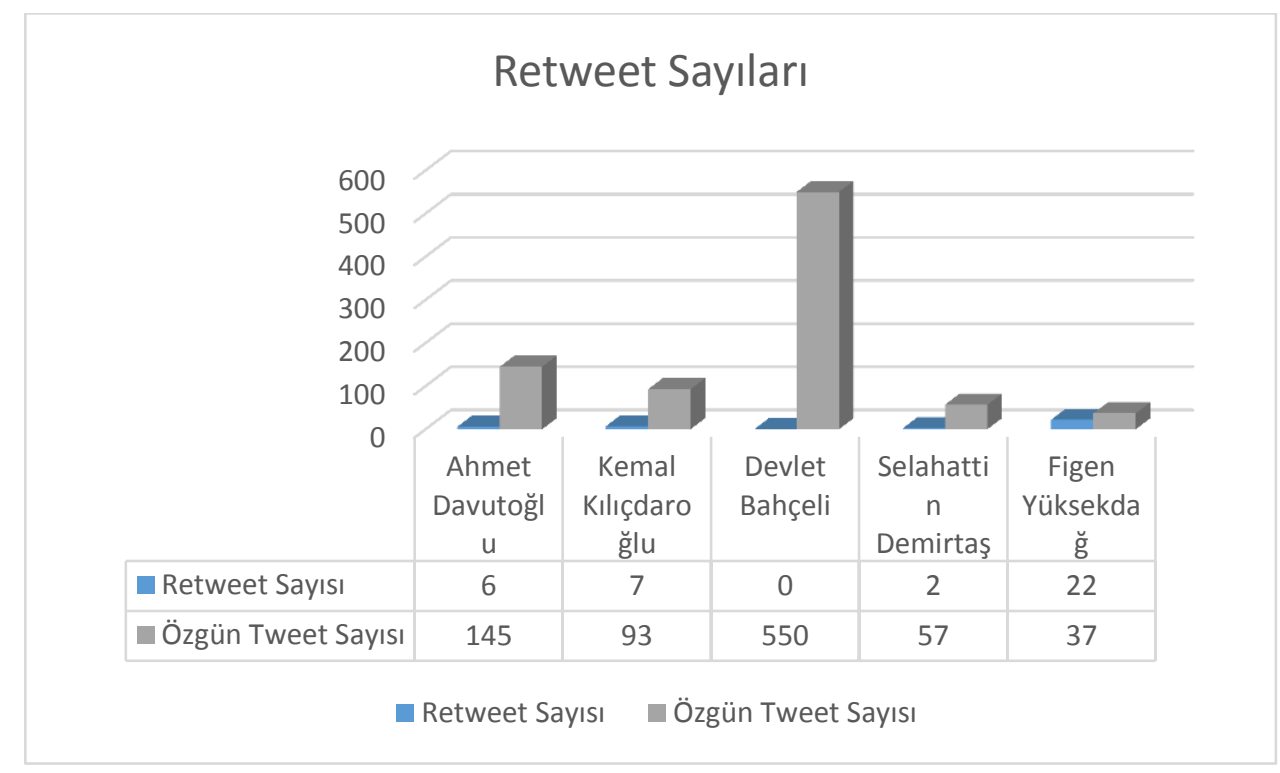

Başka bir kullanıcıdan bahsetmek ve tweetinin onun tarafından görülmesini sağlamak için kullanıcı adının belirtildiği tweetler, mention olarak tanımlanmaktadır. Tweet, @ işareti ile kullanılarak, söz etme ve/veya bahsetme anlamı taşır.

Liderlerin mention kullanımına bakıldığında Bahçeli'nin hiç mention kullanmadığı görülmektedir. Demirtaş \%20'lik kullanımla en yüksek mention kullanımına sahiptir. Diğer liderlerin kullanım oranları düşük olmakla birlikte, sırasıyla \%8 ile Yüksekdağ, \%5 ile Davutoğlu ve \% 3 ile Kılıçdaroğlu birbirini izlemektedir. Karş1lıklılık özelliği nedeniyle etkileşimsellik boyutu yüksek bir paylaşım biçimidir. $\mathrm{Bu}$ anlamda elde edilen veriler, bu uygulamanın yoğun bir biçimde kullanılmadığını göstermektedir. Demirtaş ise diğer liderlere göre daha fazla mention kullanmaktadır. Twitter'ın mention kullanım özelliği mesajın başka kullanıcının sayfasında görünmesini sağlama ve mesajın daha geniş kitleye duyurulması açısından önem taşımaktadır. 
Tablo 6. Liderlerin Mention Kullanım Oranları

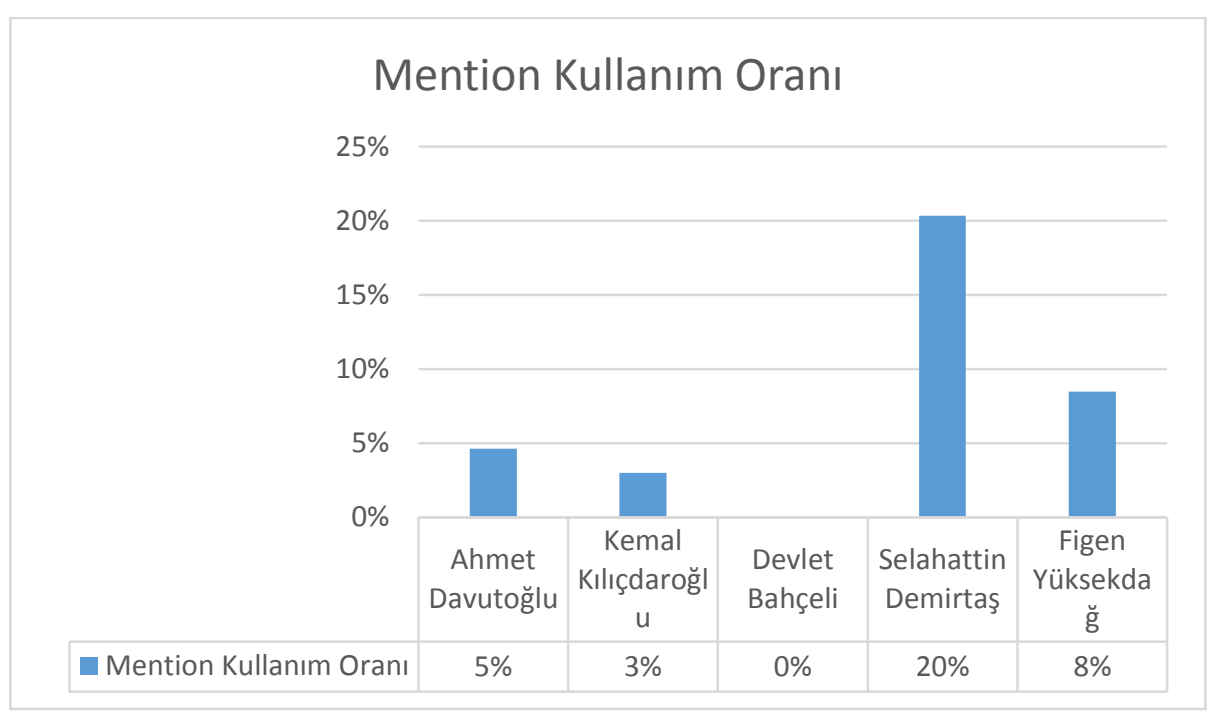

Hashtag, üzerinde konuşulmak istenen konuyla ilgili \# işaretiyle bir etiket oluşturup pek çok kişinin belirlenen konuyla ilgili görüşlerinin alınmasına olanak sağlayan bir twitter uygulamasıdır. Liderler bağlamında hashtag uygulamasının kullanımına bakıldığında, Yüksekdağ'ın oldukça yüksek oranda kullandığı dikkat çekmektedir. Davutoğlu da \%19 oranıyla yoğun kullanan liderlerden birisidir. K1liçdaroğlu'nun \%7 ve Demirtaş'ın ise \%2'lik bir oranla düşük seviyede kullandıkları görülmektedir. Aynı tweet sayısına sahip olmak ve aynı partinin eş başkanı olmakla birlikte Demirtaş ve Yüksekdağ'ın bir siyasal iletişim aracı olarak twitter kullanım biçimleri farklılık göstermektedir. En dikkat çekici hususlardan birisi de, Bahçeli'nin hashtag uygulamasını yine tercih etmediğidir. Hashtag kullanımı belirli bir konuya dikkat çekme ve özellikle belirlenen konu üzerinden karşı tarafın katılımını sağlayarak daha geniş bir kitleye ulaşmayı sağlamaktadır. Belirlenen konuya ilişkin çok sayıda katılım sağlanması ise Twitter'ın gündeminde en çok konuşulan konu olma avantajını sağlayarak mesajın etki gücünü arttırmaktadir. 
Tablo 7. Liderlerin Hashtag Kullanım Oranları

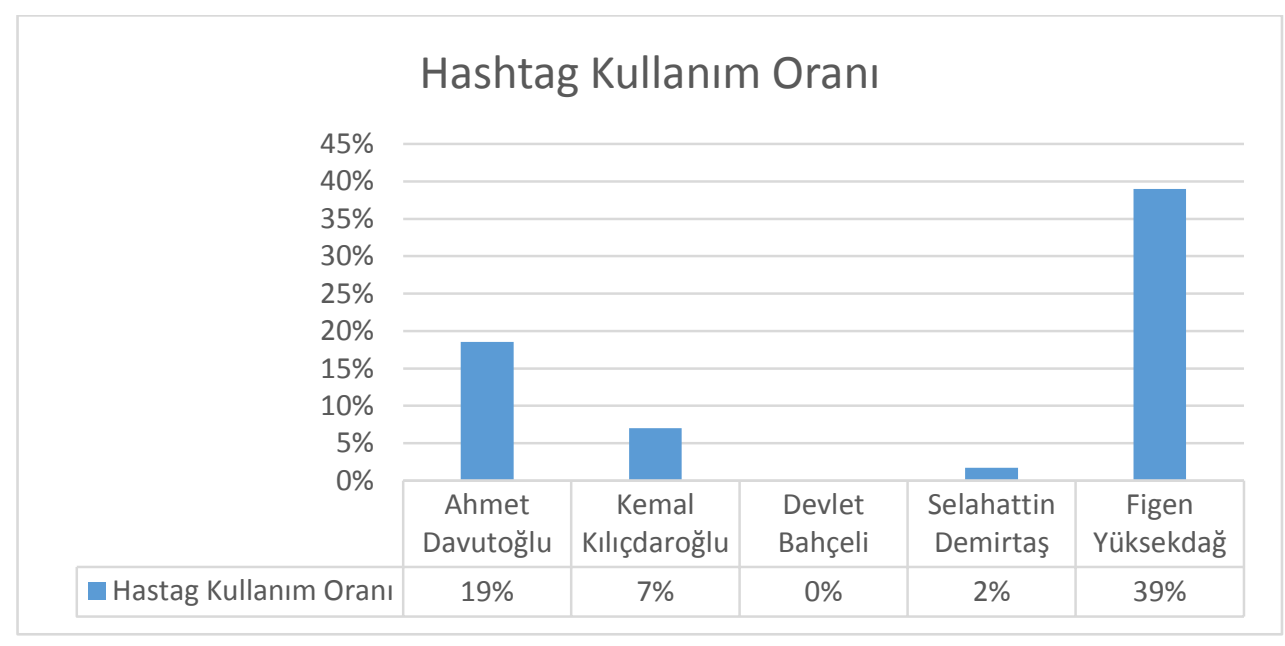

Kullanım oranları dışında beş siyasi parti liderinin kullandıkları hashtag konuları Tablo 8'de yer almaktadır. Davutoğlu, tweetleri içindeki hashtag kullanım oranı \%19 olmasına karşın en fazla konu başlığı açan lider olarak görülmektedir. Yüksekdağ ise 23 farklı konu başlığı açmıştır. Kılıçdaroğlu 4, Demirtaş ise sadece bir konu başlığına yer vermiştir. Konu başlıklarına bakıldığında, Davutoğlu'nun ele aldığı konular seçim ve gündeme ilişkin ağırlık taşırken, Kılıçdaroğlu'nun ele aldığı konular yalnızca seçime yöneliktir. Demirtaş ve Yüksekdağ'ın ise gündemde olan politik ve toplumsal olayları konu başlıklarında öne çıkardıkları dikkat çekmektedir.

Tablo 8. Liderlerin Hashtag Başlıkları

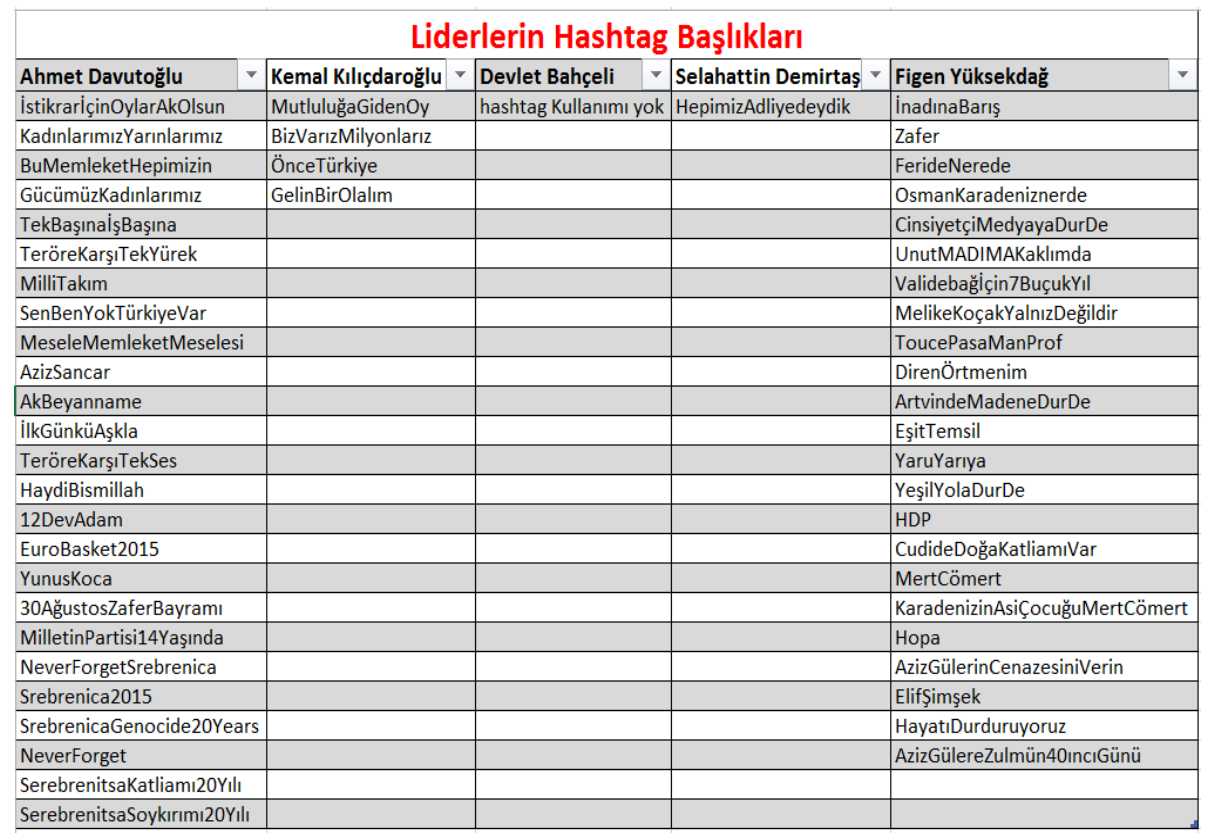


Twitter'da fotoğraf ve video kullanımı etkileşimselliğin gücünü arttırabilecek bir özellik göstermektedir. Özellikle seçime yakın dönemde parti konuşmaları, reklamları, miting konuşmaları gibi görsel ve işitsel öğelerin Twitter ortamında yer alması etkileyici özelliğini arttırmakta ve siyasal iletişimin hedef kitleye ulaşımını kolaylaştırmaktadır. Liderlerin fotoğraf ve video kullanımına bakıldığında, Yüksekdağ \%37 ile yine en yüksek orana sahiptir. HDP'nin diğer eş genel başkanı Demirtaş \%20 ile Yükssekdağ'o takip etmektedir. Onların ardından sırasıyla, \%16 ile Davutoğlu ve \%12 ile Kılıçdaroğlu gelmektedir. Bahçeli ise diğer uygulamalarda olduğu gibi fotoğraf ve video kullanımı konusunda hiç paylaşımda bulunmayarak Twitter'ın etkileşimsellik boyutunu hemen hiç kullanmamaktadır.

Tablo 9. Liderlerin Fotoğraf ve Video Kullanımı

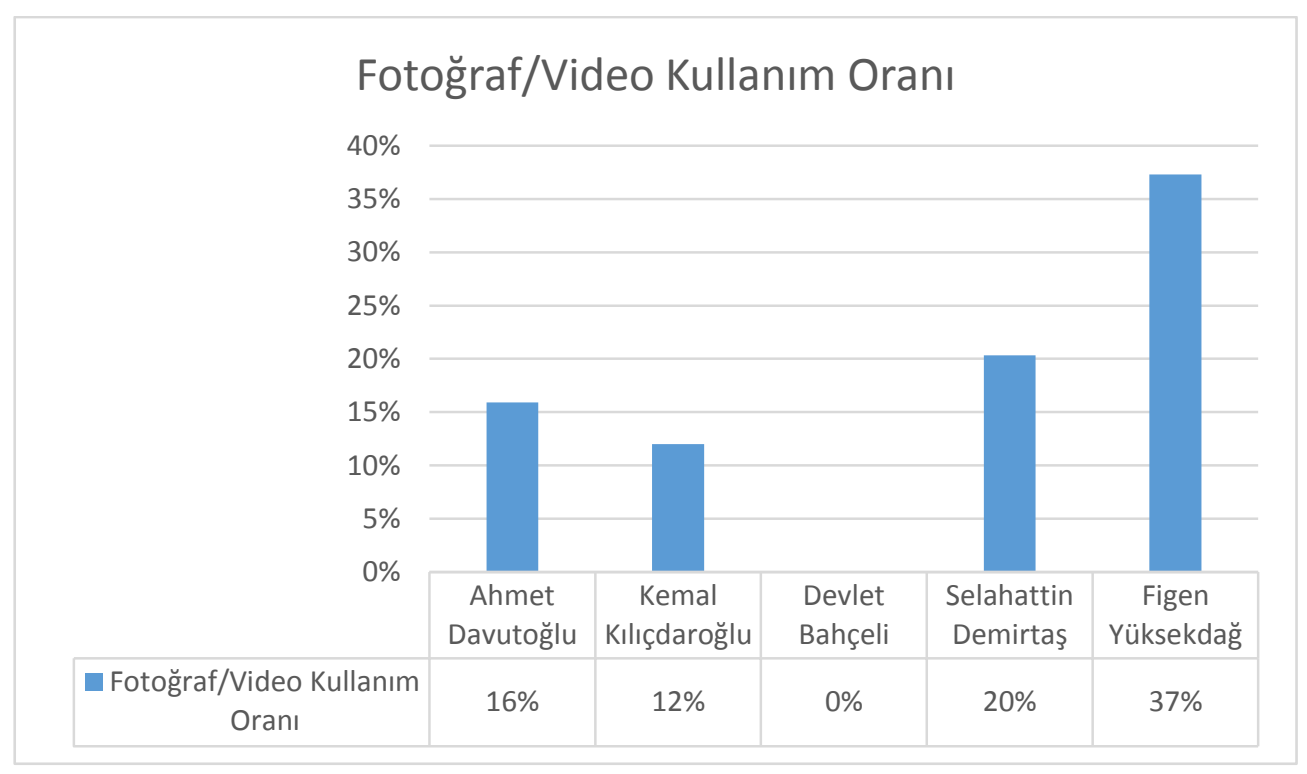

Araştırma kapsamında liderlerin tweetlerindeki konu dağılımına ilişkin bir analiz de yapılmıştır. Tweetler konu başlıklarına göre gruplandırılarak kategorilere ayrılmıştır. Bu kategoriler şu şekildedir:

Toplumsal Konular Kategorisi: Gündeme ilişkin ya da geçmişte yaşanmış önemli olaylara ilişkin liderlerin görüşlerini yansıtan tweetler,

Seçim Kategorisi: Seçime yönelik çağrılar, paylaşımlar,

Rakipler Kategorisi: Rakip siyasi parti ya da parti liderlerine ilişkin tweetler,

Vaatler Kategorisi: Seçime ve sorunların çözümüne ilişkin paylaşılan tweetler, 
Duyuru Kategorisi: Partinin açılış, toplantı, program ve miting duyurularını içeren tweetler,

Dilekler Kategorisi: Kutlama, başsağlı̆̆

Diğer Kategorisi: Kategorilendirilemeyen tweetler.

Grafik 1'de Davutoğlu'nun tweetlerinin konu dağılımına yer verilmektedir.

Grafik 1. Davutoğlu'nun Tweet Kategorileri

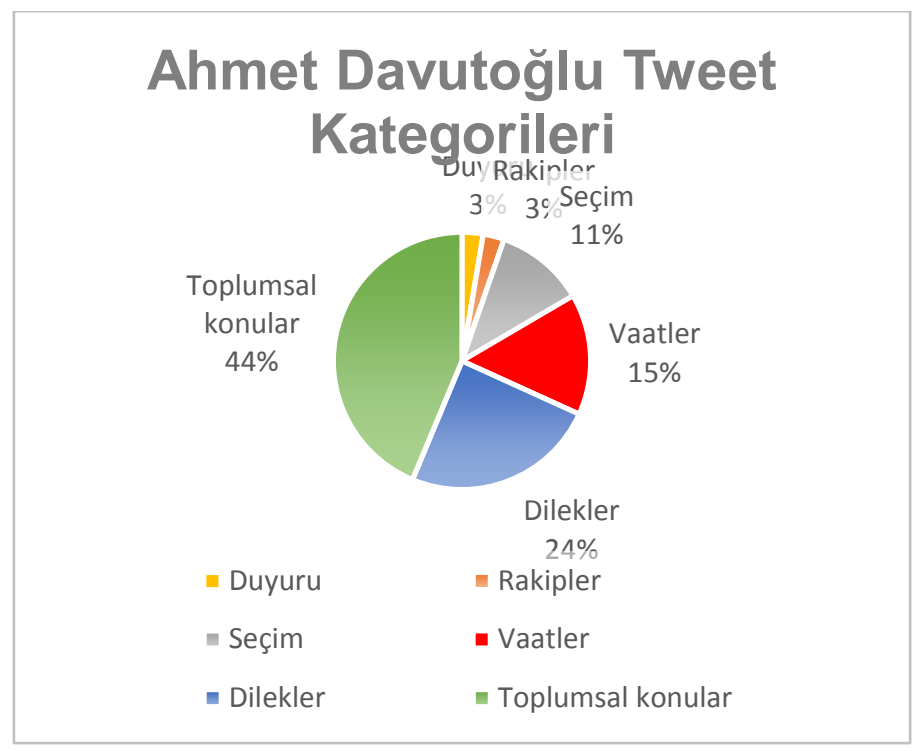

Davutoğlu'nun paylaşımlarına bakıldığında toplumsal konular en yüksek orana (\%44) sahip tweet kategorisi olarak görülmektedir. İkinci sırada, kutlama, başsağlığ 1 , teşekkür ve temenni içeren dilekler (\%24) kategorisi yer alırken, partinin seçime yönelik farklı konulardaki vaatlerini içeren vaat kategorisi ise $\% 15^{\prime}$ 'lik oranla üçüncü sırada yer almaktadır. Seçime yönelik konular \%11, rakipler \%3 ve duyurular ise yine \%3'lük bir orana sahiptir. Gündeme ilişkin konulardaki paylaşımlarda farklı dillerdeki mesajlar da dikkati çekmektedir. Davutoğlu'nun en yüksek tweet paylaşımı, terör saldırılarının yapıldığı Temmuz ayında (48 tweet) görülmektedir. Seçimin hemen öncesi olan Ekim ayındaki tweet sayısı ise 24 olarak tespit edilmiştir. Bu grafike göre, Davutoğlu'nun rakiplere yönelik bir konu stratejisi izlemek yerine, seçmene yönelik pozitif mesajlar veren bir konu stratejisi izlediği görülmektedir.

Grafik 2'de K1lıçdaroğlu'nun tweet konularına ilişkin dağılım yer almaktadır. 
Grafik 2. Kılıçdaroğlu'nun Tweet Kategorileri

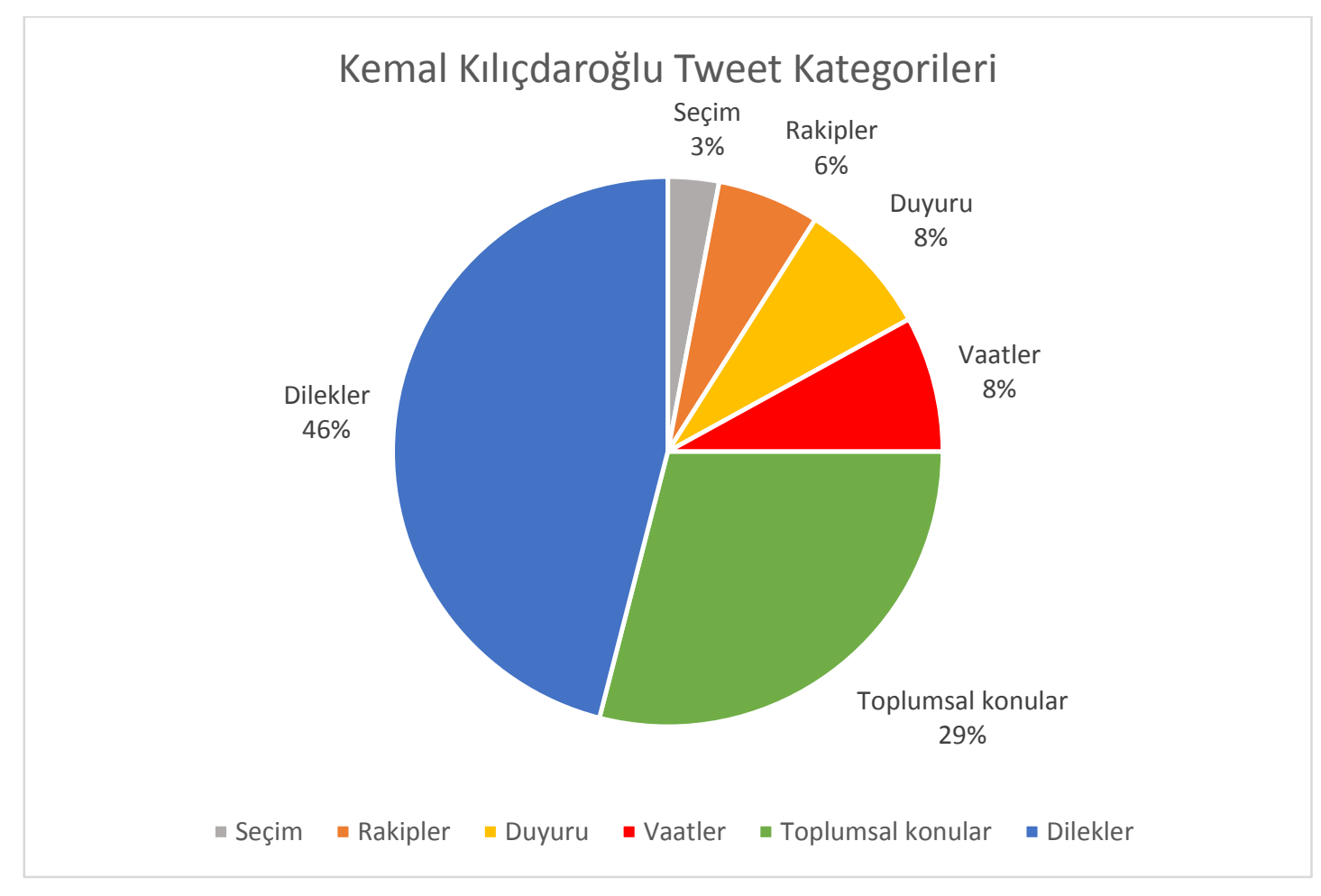

Kilıçdaroğlu'nun tweetlerinde en yüksek tweet kategorisi \%46 ile dilekler kategorisidir. Bu kategoriyi; çalışmada ele alınan dönem içinde gerçekleşen iki terör saldırısına ilişkin başsağlığı mesajları, sanat ve siyaset dünyasından kayıplara yönelik mesajlar, Cumhuriyet ve Kurban Bayramı kutlamaları, milli takım ve bilim adamlarının başarıları vb. konulardaki mesajlar oluşturmaktadır. İkinci sırayı \%29 ile toplumsal konular alırken, seçim öncesi dönem olmasına karşın seçime yönelik vaatler ve duyurular $\% 8$ 'er ile oldukça düşük bir orana sahiptir. Rakiplere yönelik tweetler \%6 ile beşinci sırada bulunurken, seçim kategorisi ise \%3 ile son sıradadır. Dilekler kategorisindeki paylaşımlar hedef kitle ile iletişimimde samimi ve duyarlı bir alg1 yaratmasına karşın, Twitter ortamının seçimle bağlantılı mesajlar açısından yeterince etkin kullanılamadığ görülmektedir. Bununla birlikte, Kılıçdaroğlu'nun aylar itibariyle yaptığı paylaşımlar (Haziran 11, Temmuz 21, Ağustos 9, Eylül 15, Ekim 44 tweet), seçime doğru Twitter'daki etkinliğini giderek artırdığına işaret etmektedir.

Grafik 3, Bahçeli'nin Twitter hesabındaki konu kategorilerinin dağılımını göstermektedir. 


\section{Grafik 3. Bahçeli'nin Tweet Kategorileri}

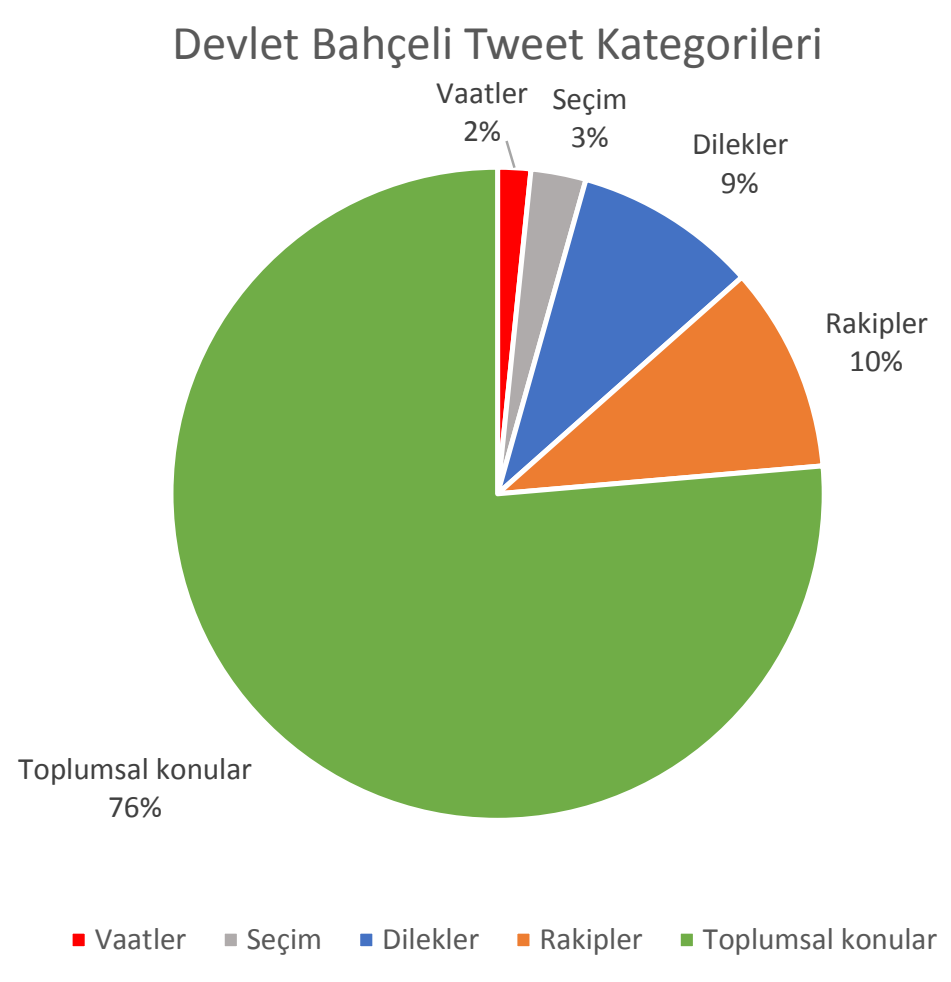

Bahçeli’nin Twitter kullanımı diğer liderlerin Twitter kullanımından farklılık göstermektedir. Şöyle ki, Bahçeli’nin Twitter hesabında dikkat çeken durum sadece özgün tweetlere yer vermesidir. Hiçbir retweet, mention, hashtag, fotoğraf, video ve link paylaşımı bulunmamaktadır. Ayrıca, hiçbir hesabı da takip etmemektedir. Bu durum, Bahçeli'nin Twitter hesabını, sosyal medyanın doğasına aykırı bir şekilde tek yönlü kullandığı ve etkileşime açık bir anlayışa sahip olmadığını göstermektedir. Tweet kategorilerinde toplumsal konulardaki paylaşımlar \%76 gibi oldukça yüksek bir orana sahiptir. Rakiplere ilişkin eleştiriler ikinci sırada \%10'luk bir oranla yer alırken, dilekler kategorisi \%9 olarak belirlenmiştir. Seçim öncesi yapılan açılış, toplantı, program ve miting gibi çalışmalara ilişkin duyurular kategorisinde hiçbir tweet bulunmamaktadır. Seçim \%3 ve vaatler kategorisi \%2 ile son sıralarda bulunmaktadır. Bahçeli'nin Twitter kullanımında öne çıkan uygulama, toplumsal konulara ilişkin görüş ve düşüncelerinin tek yönlü aktarılması biçimindedir. Ayrıca, her gün Twitter aktivitesi olmadığı ve paylaşımların yapıldığı günlerde atılan 
tweetlerin çok sayıda ve birbirini takip eder nitelikte olduğu da dikkati çekmektedir. Bahçeli aylara göre tweet paylaşımında (Haziran 93, Temmuz 98, Ağustos 140, Eylül 100 ve Ekim 119) toplumsal konuların ağırlıklı olarak ele alındığı Ağustos ayında en yüksek paylaşımı yapmaktadır.

Grafik 4 ve Grafik 5'te HDP eş başkanları Demirtaş ve Yüksekdağ'ın Twitter kullanımına ilişkin konu dağılımları görülmektedir.

Grafik 4. Demirtaş’ın Tweet Kategorileri

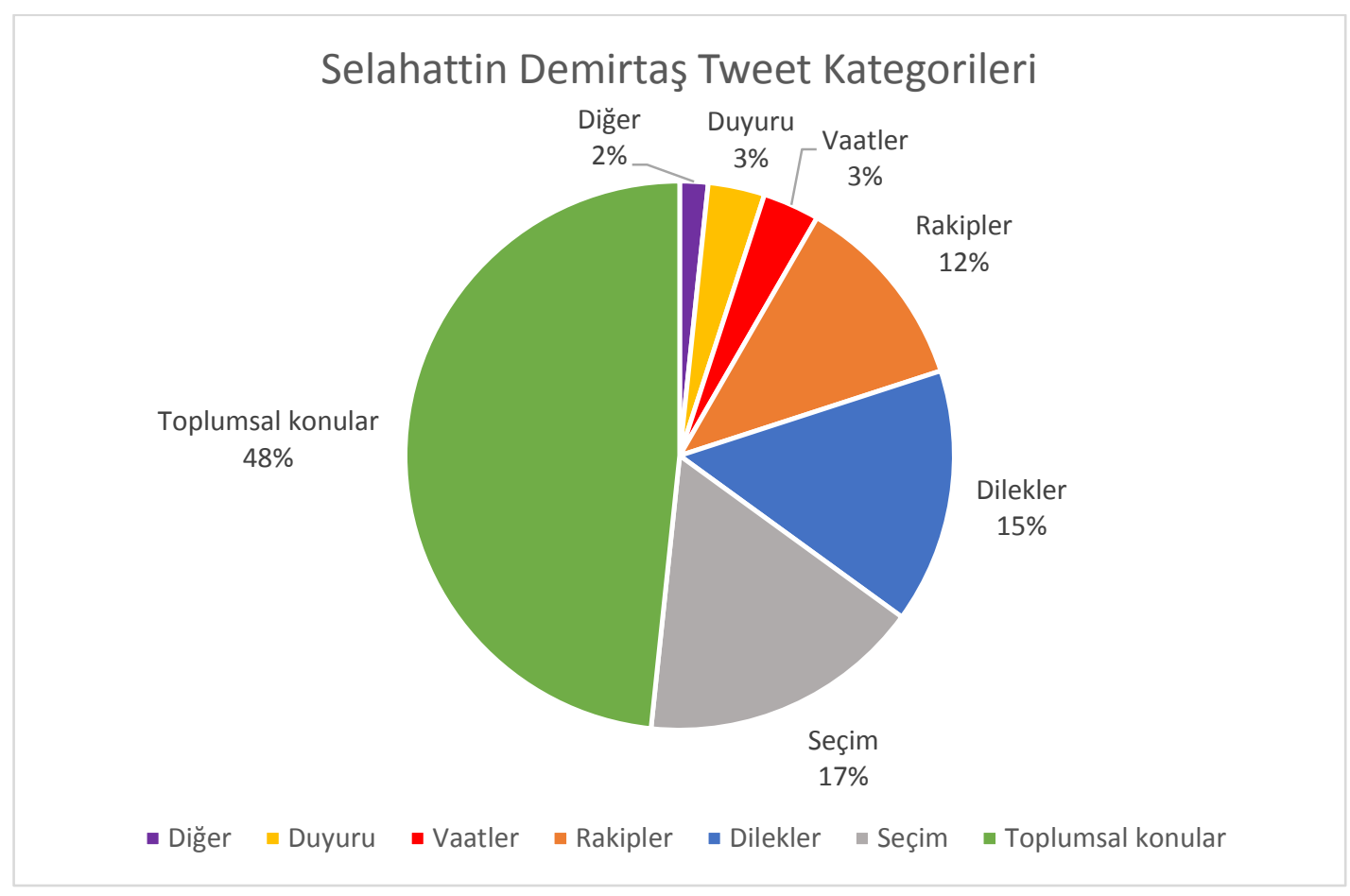

Demirtaş'ın paylaşımlarında ilk sırayı \%48'lik oranla toplumsal konular almaktadır. Özellikle gündeme ilişkin konularda tweet sayısı artmaktadır. Seçime yönelik paylaşımlarda siyasi liderler içinde \%17 ile en yüksek tweet oranına sahip hesap Demirtaş'a aittir Bu konuyu, \%15 ile dilekler ve \%12 ile rakiplere yönelik mesajlar izlemektedir. Seçime yönelik çağrılar tweetler içinde görece yüksek oranda yer almasına karşın, seçmenlere yönelik vaatler sadece \%3 gibi oldukça düşük bir yüzde ile temsil edilmektedir. Yine, seçim öncesi faaliyetlere ilişkin duyurular da \%3'tür. Diğer kategorisinde yer alan tweetler ise \%2 oranındadır. Demirtaş'ın aylara göre tweet dağılımı Haziran 7, Temmuz 14, Ağustos 13, Eylül 9 ve Ekim 16 olarak belirlenmiştir. Seçime görece daha uzak aylardaki paylaşımlarda, toplumsal konular 
ve parti görüşleriyle bağlantılı mesajlar ağırlık kazanmaktadır. Seçim öncesi Ekim ayında ise mesajların hem sayı olarak arttığı hem de seçimin kazanılması ve HDP'ye oy verilmesi yönünde içerik taşıdığı dikkati çekmektedir. Ayrıca diğer siyasi liderlere göre seçime yönelik en yüksek oranda paylaşım, Twitter'ın seçmene mesaj vermede etkili bir araç olarak görüldüğünü de göstermektedir.

Grafik 5. Yüksekdağ’ın Tweet Kategorileri

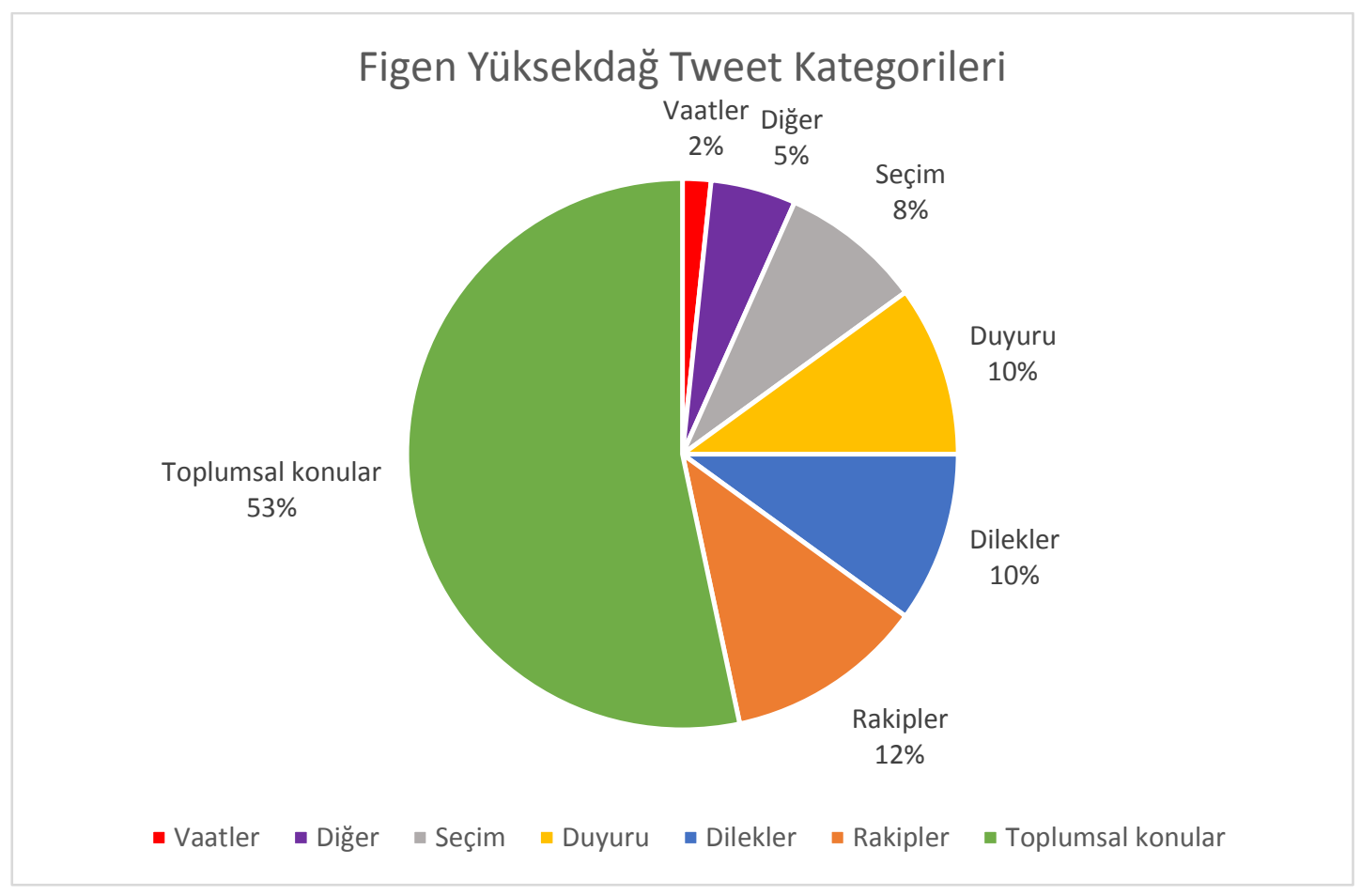

HDP eş başkanı Demirtaş ile aynı sayıda (59) tweete sahip olan Yüksekdağ'ın en fazla paylaşımda bulunduğu kategori \%53 ile toplumsal konulardır. İki eş başkanın rakipler kategorisindeki paylaşım oranları \%12 ile eşit sayıdadır. Gündeme ilişkin konularda rakiplere yönelik eleştiriler paylaşımların genel karakteristiğini oluşturmaktadır. Hesapta, dilekler ve duyurular \%10 ile eşit oranda yer almaktadır. Seçim kategorisine yönelik \%8'lik oran seçim öncesi dönem olması nedeniyle yetersiz görülmektedir. Özellikle, seçmene yönelik vaatlerin yoğunluk kazanması beklenirken \%2 gibi çok düşük bir orana sahip olması ve paylaşımların toplumsal konularda yoğunlaşması Twitter'ın kullanım amacına yönelik farklılaşmaları göstermektedir. Diğer konulardaki paylaşım ise \%5'tir. Ayrıca, Yüksekdağ'ın paylaşımlarının aylara göre dağılımına bakılacak olursa, Haziran 6, Temmuz 29, 
Ağustos 5, Eylül 6, ve Ekim 12 tweet şeklindedir. Temmuz ayında görülen artışın nedeni, bu ayda gerçekleşen terör saldırıları ve yankıları bağlamında toplumsal konuların ağırlık kazanmasıdır.

\section{Sonuç}

Seçmen kitlenin ikna edilmesi ancak başarılı bir iletişimle mümkündür. Diğer bir ifadeyle, seçmenin desteğini elde edebilmek, siyasal iletişim kampanyalarında parti ve parti liderlerinin kendilerini ne kadar iyi ifade edebildikleri ile ilişkilidir. Yeni iletişim teknolojilerinin hayatın her alanında meydana getirdiği değişim ve dönüşümler siyasal iletişimi de etkilemiştir. Çünkü, seçmen kitlesinin yoğunlukla yer aldığı ortamların mesaj iletme açısından başarılı bir şekilde kullanımı, zaman ve mekan kısıtını ortadan kaldırması, görsel işitsel destekli sunum olanağı sağlaması, siyasi liderleri sosyal medya ortamını kullanma yönünde oldukça motive etmiştir.

Çalışmanın konusu bağlamında ele alınan Twitter'ın diyaloga uygun yapısı, bu ortamın tek taraflı bilgi ve mesaj aktarımından çok iki yönlü ve paylaşımcı kullanımını gerektirmektedir. $\mathrm{Bu}$ amaçla, mecliste yer alan dört siyasi partinin liderlerinin Twitter hesapları incelenmiştir.

Ak Parti lideri Ahmet Davutoğlu Twitter'da en yüksek takipçi oranına sahip olmakla birlikte, 82 gibi oldukça az sayıda takip ettiği hesap sayısına sahiptir. Özgün tweet ağırlıklı olmak üzere az sayıda retweet bulunmaktadır. Hashtag kullanımı belirlenen süre içinde 25 konu başlığı ile etkin şekilde kullanılmaktadır. Davutoğlu'nun paylaşımlarına bakıldığında \%44 oranıyla toplumsal konular en yüksek orana sahip tweet kategorisi olarak görülmektedir. Gündeme ilişkin konulardaki paylaşımlarda konuyla ilişkili olarak farklı dillerdeki mesajlar da dikkati çekmektedir. Her gün Twitter aktivitesi olmamakla beraber gündeme ilişkin önemli olaylar tweetlerde ele alınmaktadır. Özellikle ele alınan süre aralığında gerçekleşen terör saldırılarına ilişkin mesajlar ağırlık kazanırken seçime yakın dönemde ise görsellerle desteklenmiş seçim mesajları dikkati çekmektedir.

CHP lideri Kemal K1lıçdaroğlu belirlenen dönem içinde 100 adet tweet göndermiş ve liderler içinde en çok sayıda (9722) hesabı takip eden liderdir. Takip edilen hesap sayısının fazlalığı etkili iletişim açısından önemli bir kriter olmakla 
birlikte, sadece 7 retweet, \%3 lük mention ve \%7'lik hashtag kullanımı bu etkinliği sağlamamaktadır. Ayrıca iletişimde fotoğraf ve video destekli mesajların \%12 oranında yer alması da yetersiz görülmektedir. Diğer liderlerden farklı olarak \%46 oranında dilekler kategorisi ön plana çıkmakta, ikinci sırayı ise \%29 ile toplumsal konular oluşturmaktadır. Seçim öncesi dönem olmasına karşın seçime yönelik vaatler ve duyurular düşük bir yüzde ile tweetler arasında yer almaktadır. Kutlama, başsağlığı, teşekkür ve temennilerin iletilmesi hedef kitlede olumlu ve samimi bir alg1 yaratmakla birlikte, seçimle bağlantılı mesajlar açısından Twitter'ın yeterince etkin kullanılamadığı görülmektedir.

MHP lideri Devlet Bahçeli Twitter hesabında sadece özgün tweetlere yer vermektedir. Hiçbir retweet, mention, hashtag, fotoğraf, video ve link paylaşımı bulunmamaktadır. Ayrıca hiçbir hesabı da takip etmemektedir. Bu durum Bahçeli'nin Twitter hesabını tek yönlü kullandığı ve etkileşime açık bir anlayışa sahip olmadığını göstermektedir. Tweet kategorilerinde toplumsal konulardaki paylaşımlar \%76 gibi oldukça yüksek bir orana sahiptir. Seçim öncesi yapılan çalışmalar kapsamında partinin açılış, toplantı, program ve miting duyurularına ilişsin duyurular kategorisinde hiçbir tweet bulunmamaktadır. Seçim ve vaatler kategorileri ise son siralarda bulunmaktadır. Ayrıca her gün Twitter aktivitesi olmadığı ve paylaşımların yapıldığı günlerde atılan tweetlerin çok sayıda ve birbirini takip eder nitelikte olduğu da dikkati çekmektedir. 550 adet tweetle en yüksek tweet sayısına sahip olan Bahçeli, Twitter ortamını en yoğun ama tek yönlü kullanan bir lider görüntüsü çizmektedir. Tweetlerde seslenilen hedef kitle olarak gençler ön plana çıkmaktadır. Bu durum gençlerin sosyal medya kullanımlarının daha fazla olması ve özellikle Twitter ortamının genç seçmene ulaşılabilecek bir araç olarak görülmesi şeklinde yorumlanabilir.

HDP eş başkanları Selahattin Demirtaş ve Figen Yüksekdağ \%59'ar adet tweet ile eşit sayıda tweet atmıştır. Aynı partinin eş başkanları olmalarına rağmen Twitter kullanımındaki öncelikleri farklılık göstermektedir. Demirtaş \%48, Yüksekdağ ise \%53 ile gündemde yer alan olaylarla ilişkili toplumsal konular bağlamında en yükssek oranda paylaşımda bulunmuşlardır. Liderler içinde, seçime yönelik paylaşımlarda \%17 ile en yüksek tweet oranına sahip hesap Selahattin 
Demirtaş'a aittir. Yüksekdağ seçime yönelik tweetlerde \% 8'lik bir yüzdeye sahiptir. Bununla birlikte Yüksekdağ gündemdeki konulara dikkati çekme amaçlı 23 konu başlı̆̆ı ile hashtag açmıştır. Fotoğraf ve video kullanımı konusunda da \%37 ile en yüksek yüzdeye sahiptir. Demirtaş’ın seçim öncesi mesajları sayı ve içerik olarak seçime odaklanmaktadır. Bu durum siyasal iletişim çalışmalarında Twitter'ın seçmene yönelik mesaj verilebilecek bir araç olarak görüldüğünü göstermektedir. Yüksekdağ ise açtığı 23 farklı hashtag başlığı ve görece daha az sayıdaki seçim mesajı ile Twitter'1, seçimden çok toplumsal ve siyasal görüşleri doğrultusunda mesaj vereceği bir platform olarak kullanmaktadır.

Bir kurumun hedeflerine ulaşmak amacıyla hedef kitle ile kuracağı iletişimde tüm iletişim araçlarını birlikte ve aynı içeriklerle kullanması gerekir. Dolayısıyla, siyasi parti ve liderlerinin siyasal kampanyalarda sosyal medyayı geleneksel iletişim araç ve yöntemleriyle birlikte aynı içeriklerle kullanmaları, sosyal medyanın etki gücünü arttırmaktadır. Twitter'ın özellikle bilgi paylaşımına olanak sağlayan yapısı, hız, zaman ve mekan açısından özgürlük sağlaması, kullanıcının içerik üreterek aktif olarak katılabildiği bir ortam yaratması ve Amerikan başkanlık seçimlerindeki etkisi önemini arttırmaktadır. Türkiye'deki siyasi parti liderleri de bu gerçekten hareketle Twitter hesapları açmışlar ve Twitter'ı siyasal iletişimde bir araç olarak kullanmaya başlamışlardır.

Çalışmada ortaya çıkan nihai sonuç parti liderlerinin farklı kullanım pratiklerine işaret etmektedir. Kılıçdaroğlu daha çok dilekler başlığı altında paylaşım yapmasına karşın diğer dört liderin en çok paylaşımı toplumsal konular üzerinedir. Twitter'ın etkileşimsellik özelliğini arttıran mention, retweet, hashgtag gibi kullanımları liderler açısından farklılık göstermekle birlikte genel kullanım oranlarına bakıldığında yetersizlik göstermektedir. Bu bağlamda araştırma sonuçları Siyasal İletişim Kampanyalarında Sosyal Medyanın Kullanımı: 12 Haziran 2011 Seçimleri Twitter Örneği başlıklı çalışmanın sonuçları ile paralellik taşımaktadır. Seçim öncesi dönemde seçmenin özellikle partinin ve parti liderinin neler vaat ettiğini bilmek istediği göz önünde bulundurulursa vaatlere ilişkin mesajların azlığ siyasal iletişimin ikna edici yönünü de olumsuz etkileyebilmektedir. Bu konuda seçim sonuçları açısından bir anlam yüklenebilirse, Davutoğlu \%15 gibi paylaşımla 
dikkat çekmektedir. Yine dikkat çekici diğer bir nokta da liderlerin her gün Twitter aktivitelerinin olmamasıdır.

Siyasal iletişimde hedef kitleye ulaşabilmek, onlara yönelik ikna edici bir iletişim gerçekleştirebilmek ve onların taleplerine yönelik değişimler yapabilmek liderler açısından daha aktif kullanımı ve etkileşimsellik boyutunun etkin kullanımı ile olanaklı gözükmektedir. İçerik üretimine olanak sağlayan, katılımcılığı arttıran Twitter gibi sosyal ağların seçmen kitle ile iletişimin geliştirilebilmesi ve beklentilerin yansıtılabilmesi açısından verimli kullanımının seçim kampanyalarının başarısı üzerinde etkin bir rol oynayabileceği söylenebilir.

\section{KAYNAKÇA}

AKINCI Vural Z. Beril ve BAT, Mikail (2009). "Siyasal Seçim Kampanyalarında Yeni İletişim Teknolojileri ve Blog Kullanımı: 2008 Amerika Başkanlık Seçimlerine Yönelik Karşılaştırmalı Bir Analiz”, Journal of Yasar University, 4 (16), s. 2745-2778.

AKINCI Vural Z. Beril ve BAT, Mikail (2010).

"Yeni Bir İletişim Ortamı Olarak Sosyal Medya: Ege Üniversitesi İletişim Fa kültesine Yönelik Bir Araştırma”, Journal of Yasar University, 20(5), s. 33483382.

AKTAŞ, Hasret (2004). Bir Siyasal İletişim Aracı Olarak İnternet, Konya: Tablet Yayınları.

ALTUNAY, Meltem Cemiloğlu (2010). “Gündelik Yaşam ve Sosyal Paylaşım Ağları: Twitter ya da P1t P1t Net”, Galatasaray Üniversitesi İletişim Dergisi, Say1 12, s. 31-56.

AZİZ, Aysel (2014). Siyasal İletişim, Ankara: Nobel.

BAYRAKTUTAN, Günseli; BİNARK, Mutlu; ÇOMU, Tuğrul; DOĞU, Burak; İSLAMOĞLU, Gamze; AYDEMIR, Aslı Telli (2012). "Sosyal Medyada 2011 Genel Seçimleri: Nicel-Nitel Arayüzey İncelemesi”, Selçuk Üniversitesi İletişim Fakültesi Dergisi, Cilt:7, Sayı:3, s. 5-29. 
BOSTANCI, Mustafa (2014). "Siyasal İletişim 2.0”, Erciyes İletişim Dergisi Akademia, Cilt:3, Sayı:3, s. 84-96.

ÇETIN, Selçuk (2015). “2014 Yerel Seçimlerinde Büyükşsehir Belediye Başkan Adaylarının Twitter Kullanımları Üzerine Karşılaştırmalı Analiz”, Global Media Journal TR Edition, 5 (10) Spring, s. 87-119.

DOĞU, Burak; BAYRAKTUTAN, Günseli; BİNARK, Mutlu; ÇOMU, Tuğrul; İSLAMOĞLU, Gamze; AYDEMİR, Aslı Telli (2013). "Milliyetçi Hareket Partisi'nin Alternatif Mecra Arayışında 2011 Genel Seçimleri ve Twitter Kullanımı”, Global Media Journal TR Edition, (4) 8, s. 96-124.

GENEL, Mehmet Gökhan (2012). "Siyasal İletişim Kampanyalarında Sosyal Medyanın Kullanımı: 12 Haziran 2011 Seçimleri Twitter Örneği”, The Turkish Online Journal of Design Art and Communication, TOJDAC October Volume 2, Issue 4, s. 23-31.

GERAY, Haluk (2014). Toplumsal Araştırmalarda Nicel ve Nitel Yöntemlere Giriş, Ankara: Umuttepe Yayınları.

KALKAN, Veli Denizhan; KESKİN, Halit; AKGÜN, Ali E. (2002). "İnternet ve Siyasal Yaşam: Literatür Değerlendirmesi ve Bir Sentez Arayışı”, VIII. Türkiye'de İnternet Konferansı Bildirileri, 19-21 Aralık 2002, Askeri Müze/Harbiye Kültür Sitesi, İstanbul.

KARAÇOR, Süleyman (2009). "Yeni İletişim Teknolojileri, Siyasal Katılım, Demokrasi”, Celal Bayar Üniversitesi İktisadi İdari Bilimler Fakültesi, Yönetim ve Ekonomi, Cilt:16, Sayı:2, s. 121-131.

KILIÇASLAN, Çakmak Emine (2008). İdeoloji ve Medya İlişkisi, İstanbul: Kriter Yayınları.

LILLEKER, Darren G. (2013). Siyasal İletişim Temel Kavramlar, İstanbul: Kaknüs Yayınları.

ODABAŞI, H.Ferhan; MISIRLI, Özge; GÜNÜÇ, Selim; TİMAR, Ş. Zeynep; ERSOY, Mehmet; SOM, Seçil; DÖNMEZ, Fevzi İnan; AKÇAY, Tayfun; 
EROL, Osman (2012). "Eğitim için Yeni Bir Ortam: Twitter", Anadolu Journal of Educational Sciences International, January, 2(1), s. 89-103.

ÖKSÜZ, Onur ve YILDIZ, Elif Turan (2004). “Siyasal İletişimde İnternet Kullanımı: Türkiye ve ABD’deki Siyasal Partilerin Web Sitelerinin Karşılaştırmalı Analizi." 2nd International Symposium, Communication in the Millenium'da sunulmuş bildiri. Tam metin, http://cim.anadolu.edu.tr/pdf/2004/1130855423.pdf, Erişim Tarihi: 23.10.2015.

ÖZKAN, Abdullah (2007). Siyasal İletişim Stratejileri, İstanbul: Tasam Yayınları.

ÖZSOY, Osman (2009). Seçim Kazandıran Siyasal İletişim, İstanbul: Pozitif Yayınları.

ÖZTÜRK, İlknur Doğu (2014). "Siyasal İletişim Aracı Olarak Sosyal Medya: 2012 Amerikan Başkanlık Seçimlerinde Twitter Kullanımı Üzerine Bir Araştırma”, (Editör) İdil Sayımer. Yeni Medya Araştırmaları, İstanbul: Literatürk Academia, s. 399-436.

SAYIMER, İdil (2012). Sanal Ortamda Halkla İlişkiler, İstanbul: Beta.

SÜTÇÜ, Günseli Bayraktutan (2007). “İktidarın Müzelerinin Sanal Uzamdaki Varlığı Üzerinden Siyasal İletişimi Yeniden Düşünmek”, (Derleyen) Mutlu Binark. Yeni Medya Çalışmaları, Ankara: Dipnot Yayınları, s. 71-95.

ŞENER, Gülüm; EMRE, Perrin Öğün; AKYILDIZ, Fatih (2015). “Türkiye'de Sosyal Medyanın Siyasi Katılıma Etkileri”, Folklor/Edebiyat Dergisi, Yeni Medya Çalışmaları Özel Sayısı, Cilt 21, Sayı 83, 3, s. 75-98.

STIEGLITZ, Stefan; BROCKMANN, Tobias; XUAN, Linh Dang (2012). "Usage of Social Media for Political Communication", Pacific Asia Conference on Information Systems AIS Electronic Library.

TAMÇELIKK, Soyalp (2014). “Sosyal Medyanın Türkiye'de Yeni Özgürlük Alanlarını Belirlemedeki Etkisi ve Yerel Seçimlerde Siyasal İletişimle Kolektif Kimlik Oluşumundaki Rolü’, İletişim ve Diplomasi Dergisi, Sayı: 3, Y1l: 2, s. 27-47. 
TUMASJAN, Andranik; SPRENGER, Timm O.; SANDNER, Philipp G. ; WELPE, Isabell M. (2010). "Predicting Elections with Twitter: What 140 Characters Reveal about Political Sentiment", Proceedings of the Fourth International AAAI Conference on Weblogs and Social Media. https://www.aaai.org/ocs/index.php/.../1852. 178-185. Erişim Tarihi: 16.01.2016.

YALIN, Bahar Eroğlu (2006). "Siyasal İletişimin Reklam Boyutuna İlişkin Kuramsal Bir İnceleme”, İstanbul Üniversitesi İletişim Fakültesi Dergisi, 25, s. 169180.

YILDIRIM, Yılmaz (2012). "İletişimsel Eylem Kuramı Işı̆̆ında Siyasal İletişim ve AK Parti Örneği”, Akademik İncelemeler Dergisi (Journal of Academic Inquiries), Cilt:7, Sayı:1, s. 195-226.

http://www.internethaber.com/adaylara-secim-kazandiran-tuyolar-770978h.htm Erişim Tarihi: 05.10.2015.

https://tr.wikipedia.org/wiki/Twitter. Erişim Tarihi: 16.11.2015.

http://www.statisticbrain.com/ Erişim Tarihi: 24.10.2014. 